OPEN ACCESS

Edited by:

Cristiano Spada,

Fondazione Poliambulanza Istituto

Ospedaliero, Italy

Reviewed by:

Enrique Quintero,

University of La Laguna, Spain

Bita Geramizadeh,

Shiraz University of Medical

Sciences, Iran

*Correspondence:

Rupinder Mann

rupindrmann@yahoo.com

Specialty section:

This article was submitted to

Gastroenterology,

a section of the journa

Frontiers in Medicine

Received: 21 June 2021 Accepted: 27 December 2021

Published: 20 January 2022

Citation:

Mann R, Gajendran M, Umapathy C, Perisetti A, Goyal H, Saligram S and

Echavarria J (2022) Endoscopic Management of Complex Colorectal Polyps: Current Insights and Future Trends. Front. Med. 8:728704. doi: 10.3389/fmed.2021.728704

\title{
Endoscopic Management of Complex Colorectal Polyps: Current Insights and Future Trends
}

\begin{abstract}
Rupinder Mann ${ }^{1 *}$, Mahesh Gajendran ${ }^{2}$, Chandraprakash Umapathy ${ }^{3}$, Abhilash Perisetti ${ }^{4,5}$ Hemant Goyal $^{6}$, Shreyas Saligram ${ }^{3}$ and Juan Echavarria ${ }^{3}$

${ }^{1}$ Department of Internal Medicine, Saint Agnes Medical Center, Fresno, CA, United States, ${ }^{2}$ Paul L. Foster School of Medicine, Texas Tech University Health Sciences Center, El Paso, TX, United States, ${ }^{3}$ Division of Gastroenterology, Long School of Medicine, University of Texas Health San Antonio, San Antonio, TX, United States, ${ }^{4}$ Department of Gastroenterology and Hepatology, The University of Arkansas for Medical Sciences, Little Rock, AR, United States, ${ }^{5}$ Interventional Oncology and Surgical Endoscopy (IOSE), Parkview Health, Fort Wayne, IN, United States, ${ }^{6}$ The Wright Center for Graduate Medical Education, Scranton, PA, United States
\end{abstract}

Most colorectal cancers arise from adenomatous polyps and sessile serrated lesions. Screening colonoscopy and therapeutic polypectomy can potentially reduce colorectal cancer burden by early detection and removal of these polyps, thus decreasing colorectal cancer incidence and mortality. Most endoscopists are skilled in detecting and removing the vast majority of polyps endoscopically during a routine colonoscopy. Polyps can be considered "complex" based on size, location, morphology, underlying scar tissue, which are not amenable to removal by conventional endoscopic polypectomy techniques. They are technically more challenging to resect and carry an increased risk of complications. Most of these polyps were used to be managed by surgical intervention in the past. Rapid advancement in endoscopic resection techniques has led to a decreasing role of surgery in managing these complex polyps. These endoscopic resection techniques do require an expert in the field and advanced equipment to perform the procedure. In this review, we discuss various advanced endoscopic techniques for the management of complex polyps.

Keywords: colorectal polyp, colorectal cancer, endoscopic mucosal resection, endoscopic submucosal dissection, colonoscopy

\section{INTRODUCTION}

Colorectal cancer (CRC) is the third most common cancer diagnosed in both men and women in the United States each year $(1,2)$. In 2020, it was estimated that 149,500 adults were diagnosed with CRC. In terms of mortality, CRC ranks second as a cause of cancer mortality in both men and women combined, accounting for $\sim 53,200$ deaths in 2020 (2). The modifiable risk factors in CRC include smoking, high alcohol consumption, unhealthy diet, physical inactivity, and excessive weight attributing to more than half of cases of CRC (2). Most cases are preventable by appropriate screening and surveillance $(3,4)$.

The adenoma to carcinoma sequence is a well-established phenomenon in which normal colonic epithelium undergoes a series of genetic mutations that lead to cytological dysplasia and cancer $(5,6)$. The pathogenesis of genetic instability in CRC involves three major pathways: chromosomal instability (CIN), microsatellite instability (MSI), and CpG island methylator phenotype (CIMP) 
pathways (7). It is a slow process, usually takes 10-20 years, allowing effective detection of these polyps by screening colonoscopy (8). This sequence can be interrupted by polypectomy, thus decreasing the incidence and mortality from CRC (9-11). Although majority of CRC (70\%) arises from adenomatous polyps, in about $25-30 \%$ of the cases, CRC develops from sessile serrated lesions (SSL) through the SSL-tocarcinoma pathway, mostly from the right colon. Most of the current literature on colon polyp progression to cancer is based on adenoma-carcinoma sequence, and thus in review, most of the information is inclined toward adenomatous polypectomy removal. Further changes will likely be seen in the future as more data emerges on the SSL to cancer pathways $(12,13)$.

The key variable in CRC prevention is polypectomy. There is no data from randomized controlled trials (RCT) to determine the effect of polypectomy on CRC incidence and mortality. The National Polyp Study is a pivotal study which provided strong evidence that polypectomy prevents CRC (9). In the National Polyp Study, 1,418 patients were included who had at least one adenoma resected during the colonoscopy and they were followed for a mean of 6 years. The incidence of CRC in the study cohort was significantly lower (76\%) than expected on the basis of the rate in the Surveillance Epidemiology and End Results group. Furthermore, no CRC deaths were reported. In the longterm National Polyp Study follow-up study of 2,602 patients, the CRC mortality was reduced by $53 \%$ (95\% CI $20-74 \%$ ), when compared to the Surveillance Epidemiology and End Results population when followed for 23 years after polypectomy (10). A population based study from Germany showed that colonoscopy and polypectomy resulted in decreased CRC incidence and mortality, 10 years after the inclusion of colonoscopy to the national cancer screening program (14). There are three ongoing European Polyp Surveillance (EPoS) studies investigating the optimal surveillance strategies following adenoma and serrated polyp removal. EPOS I and II are randomized controlled trials, and EPOS III is observational. In EPOS I, 13,766 patients with low-risk adenomas (1-2 tubular adenomas of size $<10 \mathrm{~mm}$ with low-grade dysplasia) are randomized to surveillance after 5 and 10 years or 10 years only. In EPOS II, 13,704 patients with highrisk adenomas (3-10 adenomas or adenomas $\geq 10 \mathrm{~mm}$ or with high-grade dysplasia or $>25 \%$ villous features) are randomized to surveillance after 3,5 , and 10 years or 5 and 10 years only. EPOS III is an observational study where patients with serrated polyps $\geq 10 \mathrm{~mm}$ at any colorectal location or serrated polyps $\geq 5 \mathrm{~mm}$ proximal to the splenic flexure will undergo surveillance colonoscopy, 5 and 10 years after baseline colonoscopy. The primary endpoint of EPoS trials is the incidence of CRC, and it will be compared in all three different arms. This is the first longterm randomized trial to address surveillance after colorectal polyp removal (15).

More than $90 \%$ of polyps detected during screening colonoscopies are small ( $<10 \mathrm{~mm}$ in size), mostly benign, and do not contain advanced disease. These can be easily managed by conventional cold forceps or by snare polypectomy (12, 16-18). Around $10-15 \%$ of colorectal polyps are considered "complex" as they are difficult to be appropriately removed with these conventional endoscopic methods due to their size, location, and morphology. This review aims to discuss complex polyps and provides in depth overview of different endoscopic methods for removing these complex polyps. We also discuss various complications associated with these procedures and also future directions in the field.

\section{COMPLEX POLYP}

Complex colon polyps are generally characterized as any lesion whose endoscopic resection is technically challenging due to the size $(>20 \mathrm{~mm}$ ), the shape (flat/bulky), extent (polyps crossing two haustral folds, and polyps occupying more than a third of lumen circumference), location (right side, ileocecal valve, dentate line), or due to the presence of fibrosis as a consequence of large laterally spreading lesions (LSL) or previous attempts of endoscopic resection (ER) (19-25). These complex polyps carry an increased risk of colorectal cancer, high recurrence rates in the range of 10-20\% after piecemeal resection, risk of adverse events with resection, increased risk of interval cancer after incomplete resection, and potential for increased medicolegal risks $(26,27)$.

Approximately $10 \%$ of polyps are incompletely resected, mainly due to size and morphology, which might contribute to interval cancer (28). Most large polyps can be effectively and safely resected by advanced endoscopic techniques, such as endoscopic mucosal resection (EMR) and submucosal endoscopic dissection (ESD) (12). These techniques are usually indicated when polyps are confined to the colonic mucosa (epithelium, lamina propria, and muscularis mucosa), an area where there is no lymphatic drainage, and the risk of lymph node metastasis (LNM) is extremely low (29). Selected superficially invasive cancers can also be resected by en-bloc EMR or ESD. Endoscopic resection of unrecognized malignant polyps with superficial submucosal invasive cancer (SMIC), with subsequent surgical resection, is not associated with increased risk of lymph node metastasis recurrence or decreased long-term recurrencefree survival, even with high-risk histologic features (30, 31).

Malignant polyps, those which invade the submucosa (submucosal invasive cancer-SMIC) but do not extend into the muscularis propria (T1 on TNM classification), have a prevalence of about $0.2-5 \%$ (32). In large, non-pedunculated polyps, SMIC is seen in about $15 \%$ of polyps, with less than half having deep submucosal invasion (33).

\section{Classification of Polyps}

Detailed endoscopic assessment of a lesion with high-definition imaging is a critical first step for the optimal management of colorectal polyps. However, high-definition white light evaluation alone for features such as fold convergence, edge retraction, expansion/thickened folds, firm consistency, erythema is not enough for an assessment of SMIC. Increasing size, recto-sigmoid location, and surface morphology have been associated with an increased risk of SMIC (34-36). Lateral spreading lesions (LSL), polyps that spread laterally and circumferentially rather than vertically, are commonly seen in practice (Figure 1). These lesions can be large and technically challenging to remove due to size, location, and fibrosis. The frequency of invasive cancer in homogeneous granular lateral 

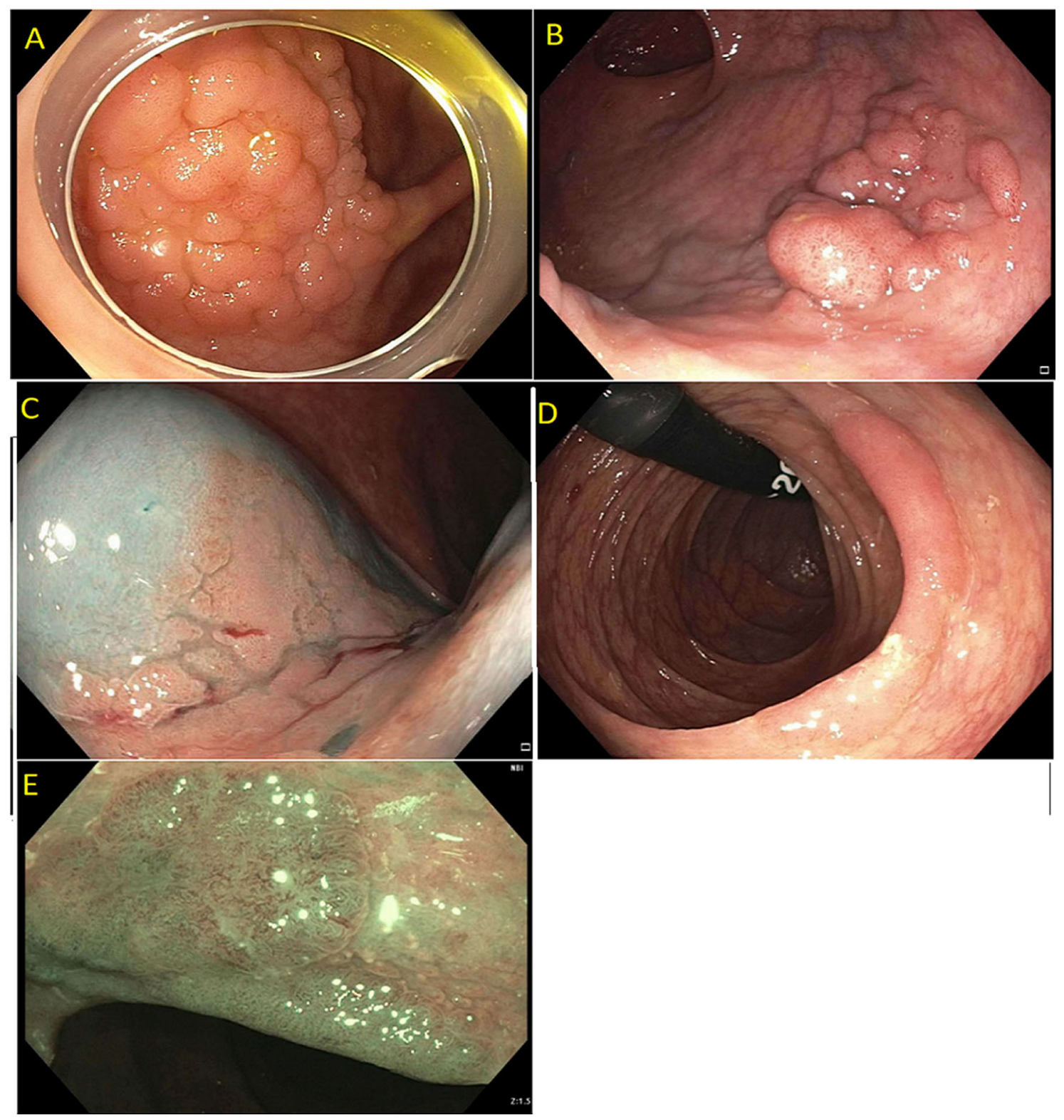

FIGURE 1 | (A) Granular lateral spreading lesion; (B) Granular lateral spreading lesion with dominant nodule; (C) Non-granular lateral spreading lesion. These lesion have a higher risk of fibrosis and invasive cancer. Polyp was tubular adenoma; (D) Non-granular lateral spreading lesion on white light; (E) Non-granular lateral spreading lesion on Narrow Band Imaging (NBI). Histology revealed a T1 adenocarcinoma.

spreading lesions (G-LSL) tends to be lower $(<5 \%)$ than for G-LSL with a dominant nodule and for non-granular LSL (NG-LSL), which are flat or pseudo-depressed, as well as large sessile and bulky lesions of similar size (Figure 2) $(35,37)$.

Current US Multi-Society Task Force guidelines recommend endoscopic lesion assessment by using aids such as the Paris classification, virtual chromoendoscopy (such as Narrow Band Imaging, or dye spray chromoendoscopy (Kudo classification) for detection of features suggestive of deep SMI. The Paris classification is a morphological classification of polyps that can predict invasive disease risk in lesions (38). Based on the Paris classification, polyps can be classified as protruding (0-Is-sessile, 0 -Ip - pedunculated, and Isp-semi-pedunculated), flat (elevated 0 -IIa, flat 0 -IIb, and depressed 0 -IIc) and excavated (Type 0 -III). The type 0-III lesions are uncommon in the colon. Depressed lesions have an increased risk of malignancy (30-50\% of cases). Combining Paris classification and the LSL classification can help guide risk of SMIC. Endoscopic assessment of surface characteristic can be assisted by "real-time" manipulation of wavelengths that enhance blood vessels and delineate surface features [e.g., narrow band imaging (NBI); Olympus, Center Valley, PA and Fujinon Blue Light Imaging; Fujinon, Valhalla, 

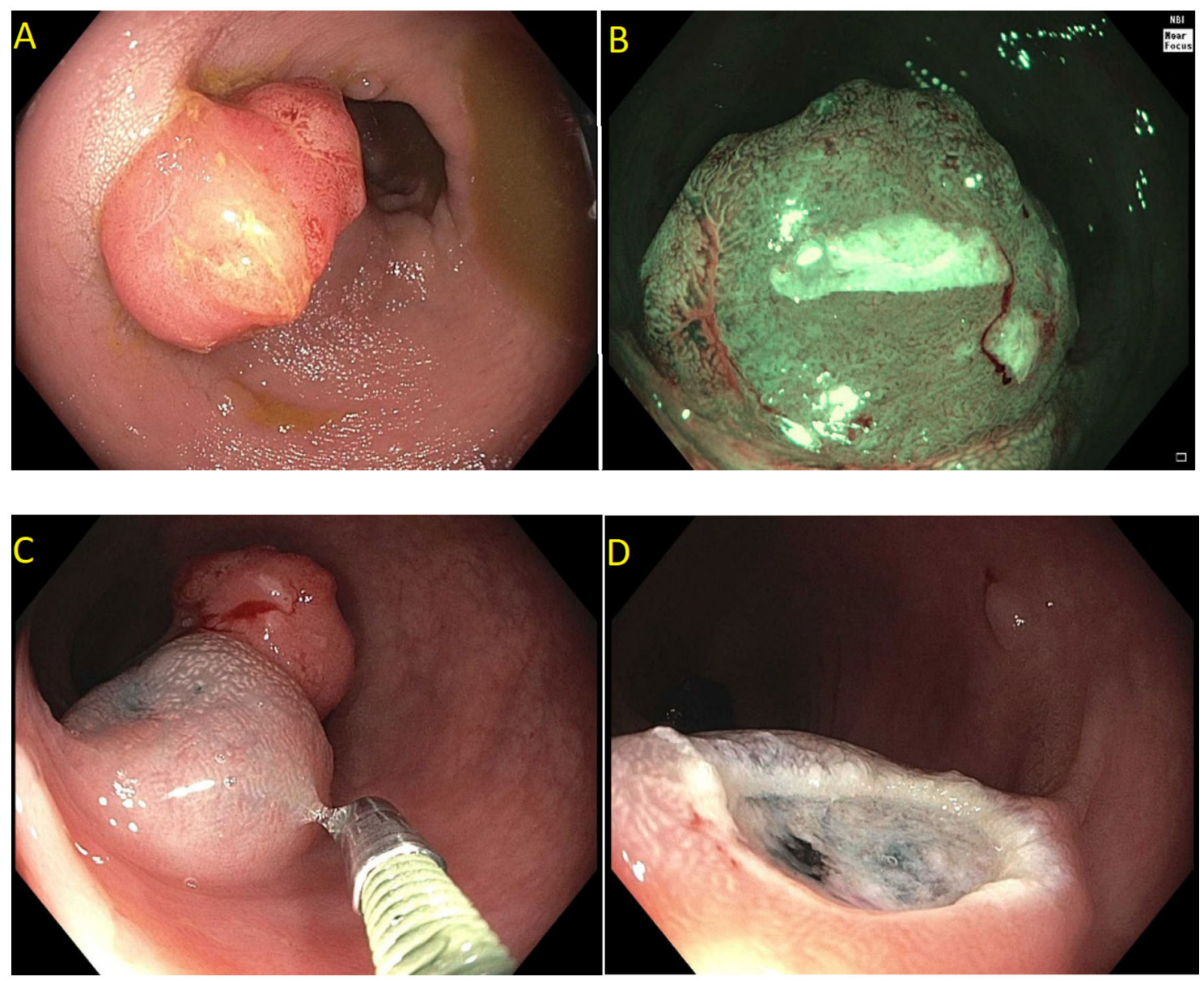

FIGURE 2 | Paris is lesion in the rectum. (A) Seen on white light; (B) Seen on Narrow Band Imaging (NBI); (C,D) Polyp raised and resected en bloc. Histology revealed a superficial $(<1 \mathrm{~mm}) \mathrm{T} 1$ tumor with lymphovascular invasion.

NY] or by postprocessor technologies that recreate the image as per the desired wavelengths (e.g., Fujinon Linked Color Imaging and Pentax iscan; Pentax Medical, Montvale, NJ) $(32,39)$. The Narrow Band Imaging International Colorectal Endoscopic (NICE) classification allows examination of the surface characteristic of a polyp based on surface appearance, color and vessel pattern. The NICE classification is highly accurate in classifying polyps into type 1 (hyperplastic), type 2 (adenoma), and type 3 (invasive cancer) (Figure 3) (4043). For the latter, the NICE criteria carry a high specificity but low sensitivity. In order to overcome this limitation, the Japanese Narrow Band Imaging Expert Team (JNET) further divides type 2 into JNET 2a (conventional adenoma) and JNET 2b (adenoma with high grade dysplasia or superficial SMIC) (Figure 4) (44). The WASP criteria, based also on NBI findings, was developed to help identify sessile serrated lesions (Figure 5). A lesser used tool in the United States, the Kudo Pit Pattern Classification, uses a combination of magnifying colonoscopy with dye spray (Indigo Carmine and Cresyl Violet) to highlight the pit pattern and determine the risk of deep submucosal invasion (45). Malignant colorectal polyps are further divided based on the histopathological feature. The Kikuchi classification system describes submucosal invasion in sessile and flat malignant colorectal polyp by dividing submucosa into three levels: $\mathrm{sm} 1$ describes invasion into the upper third of submucosa, sm2 describes invasion into the middle third of submucosa and sm3 describes invasion into the lower third of submucosa. The penetration of cancer cells into $\mathrm{sm} 3$ is associated with a higher risk of lymphatic spread. This implementation of this classification is challenging as it depends upon the quality of resected specimen as the entire submucosa is not typically included in the specimen $(46,47)$. The Haggitt criteria, used mainly for pedunculated polyps, classifies polyps into 0-4 levels based on the depth of invasion. In level 0 , dysplastic cells are limited to the mucosa, level 1 indicated invasion of cancer cells into submucosa but limited to head of polyp; level 2 indicates invasion of cancer cells into neck of the polyp; level 3 indicates when cancer cell invade stalk of the polyp, and level 4 indicate when cancer cells invade submucosa below stalk of polyp but above muscularis propria. All non-pedunculated polyps with any degree of submucosal indicate level 4 . The higher depth of invasion is found to be associated higher incidence of lymph 


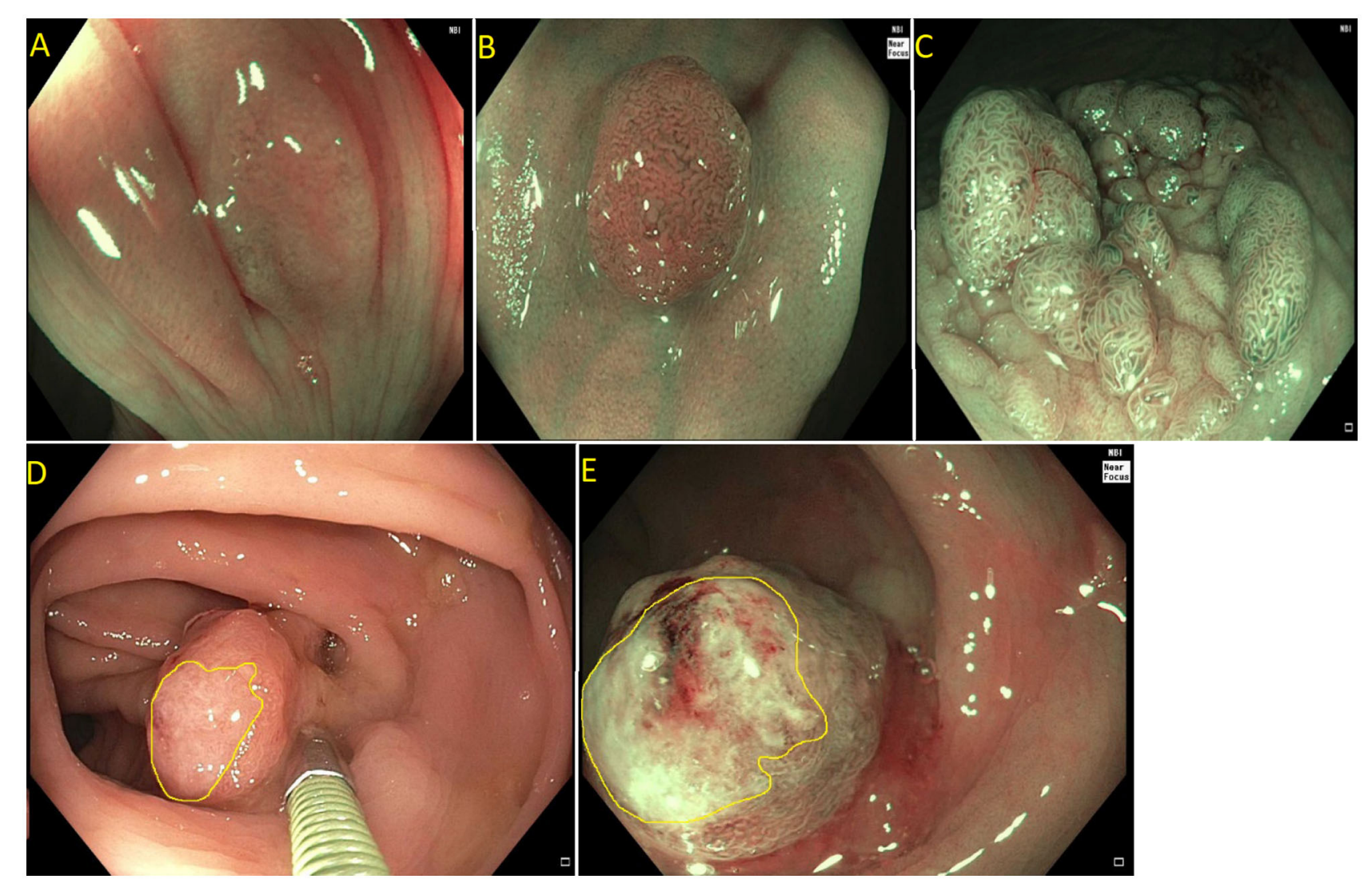

FIGURE 3 | (A) NICE type I (hyperplastic polyp); (B) Paris I-s, NICE type II (tubular adenoma without high grade dysplasia); (C) Paris Ila + is lateral spreading lesion, NICE type II (tubulovillous adenoma without high grade dysplasia); (D) NICE type III (adenocarcinoma) as see on white light. Note the invisible surface pattern with avascular area, highlighted in yellow; (E) NICE type III (Adenocarcinoma) as see under NBI.
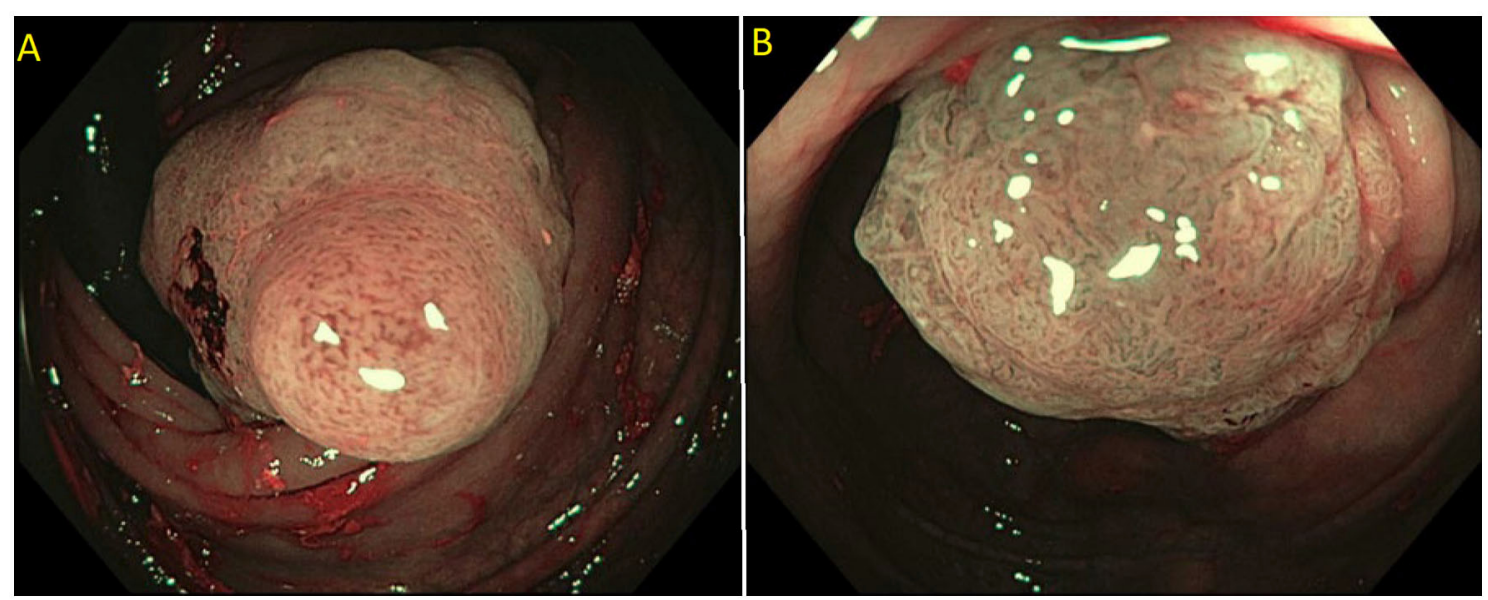

FIGURE 4 | (A) Paris 0-Ila lateral spreading lesion; (B) On NBI, lesion classified as a JNET 2B. Histology revealed tubular adenoma with high grade dysplasia.

node invasion. Like the Kikuchi classification, this classification system also depends on the resected specimen's quality, as if a pedunculated polyp is resected through the stalk, it will limit the classification $(48,49)$.
According to the 2019 Japanese Society for Cancer of the Colon and Rectum (JSCCR) guidelines, early CRC (cT1) is further categorized into slightly invasive cT1 and deeply invasive cT1. Deeply invasive cT1 is defined based on the endoscopic 


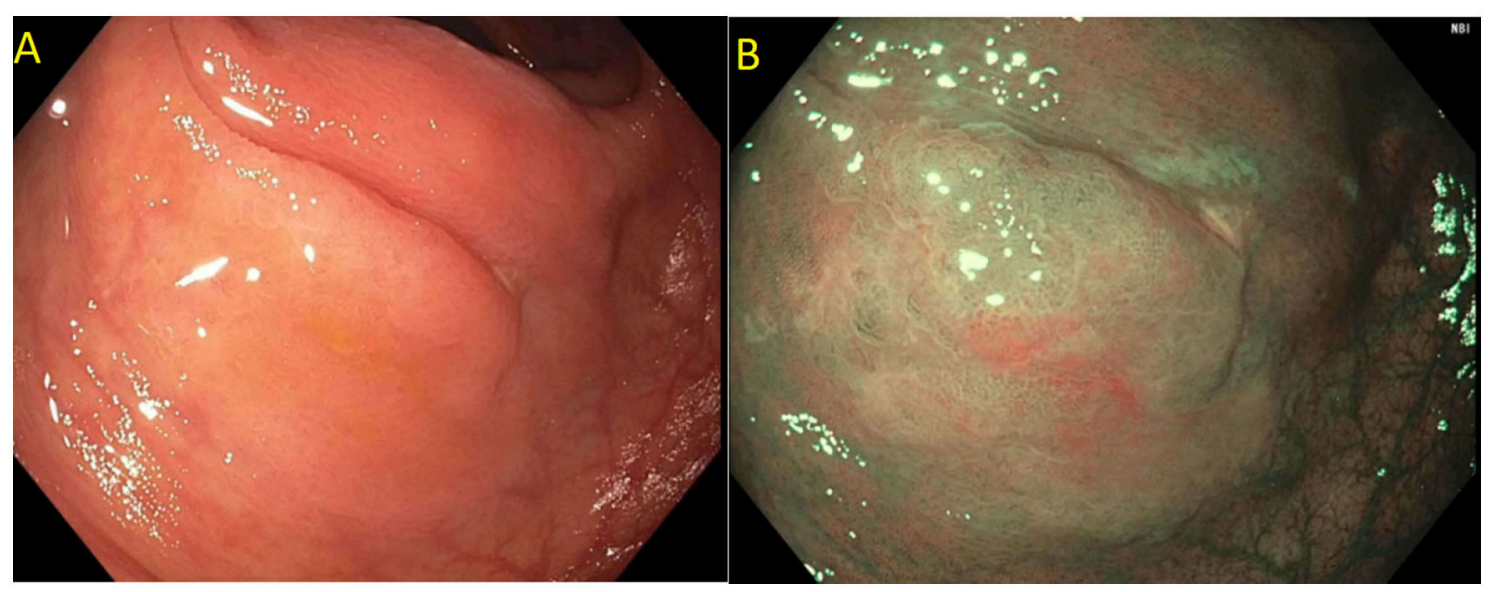

FIGURE 5 | Sessile serrated polyp on white light (A) and narrow band imaging (B). Polyp lacks a brown coloration and blood vessels or a tubular/branched surface pattern seen with tubular adenomas. Features of SSPs include clouded surface, indisctinctive borders, irregular shape, dark spots inside crypts, and mucus cap.

findings such as fullness, erosion, ulcer, deformity, rigidity, and full convergence on white light; contrast imaging; dye chromoendoscopy or image enhanced endoscopy (e.g., NBI, BLI); and endoscopic ultrasound findings. Deeply invasive cT1 lesions are managed with surgical resection with varying degrees of lymph node dissection due to high risk of lymph node metastasis. Slightly invasive cT1 (cTis) can be managed with endoscopic treatment through EMR or ESD when en bloc resection is possible due to low risk of lymph node metastasis. Whenever en bloc resection is not possible, these lesions are managed surgically. Even when endoscopic resection is successful, tumors with unfavorable histological features need lymph nodes dissection. These include: positive vertical margin, deep invasion (T1b, submucosal invasion $\geq 1,000 \mu \mathrm{m}$ ), poorly differentiated adenocarcinoma, signet-ring cell carcinoma, or mucinous carcinoma, and budding grade of $\mathrm{BD} 2 / 3$ at the site of deepest invasion (50, 51).

As per the American Joint Committee on Cancer (AJCC), early colorectal lesions, including malignant colorectal polyps, are defined as cancer invading through the muscularis mucosa into the submucosa (T1). This is further subclassified into T1a when the lesion is restricted to muscularis mucosa and $\mathrm{T} 1 \mathrm{~b}$ when the lesion is extending to submucosa. In patients with T1a lesions with low-risk features (well-or moderately differentiated adenocarcinoma, resection margins free of dysplasia or cancer, $\leq 2 \mathrm{~mm}$ depth of submucosal invasion, absence of angiolymphatic invasion), endoscopic management with EMR or ESD is sufficient if en bloc resection with negative margins can be achieved. However, for the patients with high-risk lesions and or T1b (poorly differentiated adenocarcinoma, cribriform pattern, $>2 \mathrm{~mm}$ depth of submucosal invasion, lymphatic invasion, and tumor budding) surgical resection with lymph node dissection is recommended since they have a risk of lymph node metastasis (5254).

\section{Assessment of the Technical Difficulty}

The second step in the resection of complex polyps is based on the assessment of the technical difficulty. It is well-recognized that incomplete resection is common, increases the difficulty for subsequent EMR or ESD, and is a risk factor for the need for surgical resection. The SMSA scoring system (size-S, morphology-M, site- $\mathrm{S}$, and access-A) is a simple clinical score that helps to predict the difficulty in polypectomy and identify patients who are at increased risk of incomplete resection, adverse events, and recurrence based on the above-mentioned polyp characteristics (55-57).

Complex polyps should be managed by expert endoscopists with training in advanced polypectomy techniques in a multispecialty setting due to higher risk of complications like bleeding compared to conventional polypectomy; to minimize the risk of residual polyp/recurrence; to avoid unnecessary surgeries for benign polyps, and to achieve optimal oncologic resection in case of malignant polyps (26).

\section{SURGICAL RESECTION}

It is extremely important to identify malignant polyps prior to endoscopic resection to provide the best outcomes, as polyps with deep submucosal invasion are best treated with surgical resection. However, many patients in the United States still undergo surgical resection for benign colon polyps, independent of age, race, sex, or ethnicity (58). In an analysis of a large, nationally representative sample, it was found that surgery for nonmalignant colorectal polyps has significantly increased from 5.9 in 2000 to 9.4 in 2014 per 100,000 adults (incidence rate difference, 3.56; 95\% CI 3.40-3.72) (58). Unnecessary surgical management results in increased morbidity, mortality, and direct and indirect costs $(59,60)$. In a large multicenter study, endoscopic management of large LSL by EMR was significantly more cost-effective than surgery, with a mean cost 
saving of $\$ 7,602$ per patient (95\% CI: $\$ 8,458-\$ 9,220$ ) and a reduction of inpatient hospitalization length of stay by 2.81 nights per patient (95\% CI: 2.69-2.94) (60). A prospective study from National Surgical Quality Improvement Program included 12,732 patients who underwent elective surgery to remove the non-malignant colorectal polyps. This study showed that the overall risk of 30 -day mortality was $0.7 \%$, and the risk of one or more major postoperative adverse events was $14 \%$. The index surgery resulted in ostomy among $2.2 \%$ of the study population (61).

\section{Transanal Minimally Invasive Surgery}

For the last 3 decades, trans-anal endoscopic microsurgery (TEM) has been the primary treatment for large, benign lesions of the rectum. However, the cost and technical complexity of the procedure limits its general use by colo-rectal surgeons. Transanal minimally invasive surgery (TAMIS) is a minimally invasive technique for resection of rectal tumors and was first described in 2009 by Atallah et al. as an alternative to TEM. EMR and ESD provide an endoscopic alternative for treating complex rectal lesions (62). There is very limited data comparing TAMIS with ESD.

In a single-center uncontrolled prospective study conducted in Germany, 330 patients referred for endoscopic resection of rectal large non-pedunculated colorectal polyps (LNPCPs) were included. ESD was performed in 302 patients with rectal LNPCPs, and the remaining 28 patients (advanced cancer was suspected macroscopically in 20 patients and benign lesion in 8 patients) were included. The resected lesion showed submucosal invasive cancer (SMIC) in 52 patients (17.2\%) and benign lesions in 250 patients $(82.8 \%)$. For SMIC, en bloc, R0, and curative resection were achieved in $81.4,65.1$, and $30.2 \%$ cases. Over the course of the study period, the curative resection rate increased from 13.6 to $47.6 \%, p=0.036$. En bloc and R0 resection for benign lesions was achieved in 83.2 and $70 \%$ cases, respectively. The total recurrence rate was seen in $4.8 \%$ cases for benign lesions after ESD (63). Quaresima et al. conducted a prospective study of 31 patients who underwent single-port TAMIS for mid and high rectal tumors. TAMIS was successfully completed in all cases without conversation into transabdominal surgery. The overall complication rate was $9.6 \%$, including one case of urinary tract infection, one subcutaneous emphysema, and one hemorrhoidal thrombosis. R0 resection was allowed in $96.8 \%$ of cases with TAMIS. At a mean follow-up of 30 months, a single case of local recurrence occurred after large adenoma resection (64).

A multicenter randomized controlled trial (NL7083) is currently ongoing in Netherlands comparing TAMIS and ESD for the resection of non-pedunculated rectal lesions $>2 \mathrm{~cm}$ size, with the bulk of lesion located below $15 \mathrm{~cm}$ from the anal verge (65). A target sample size is 198 patients who would be randomized into TAMIS and ESD arms. The primary endpoint is the recurrence rate at follow-up colonoscopy at 6 months. Secondary endpoints include radical (Ro-) resection rate, perceived burden and quality of life, cost-effectiveness, surgical referral rate, overall complication rate, and recurrence rate at 24 months (65).

\section{COMPLEX POLYPECTOMY}

Although most of the complex polyps are benign, and $>90 \%$ of these can be safely resected endoscopically, assessment of malignancy should be determined first, as deeply invasive cancer should be removed surgically for complete resection and histologic assessment of lymph nodes to determine lymph node metastasis. Visual signs suggestive of malignancy on colonoscopy evaluation include induration, friability, ulceration, and fixation to the colonic wall. However, large polyps can have invasive carcinoma without these signs (24, 66-70). Technique selection varies based on location, the lesion's morphology, patient's comorbidities, and endoscopist skills $(71,72)$. Advanced endoscopic techniques include EMR, ESD, hybrid techniques such as pre-cut EMR, Hybrid ESD, and novel therapies such as endoscopic full-thickness resection.

\section{APPROACH AND RESECTION TECHNIQUES}

\section{Endoscopic Mucosal Resection}

Endoscopic mucosal resection (EMR) is a technique that involves the removal of lesions within the mucosa (71). EMR technique involves submucosal injection of a solution into submucosal space, thus lifting lesion away from the muscularis propria of the colon, followed by cautery snare resection (Figure 6) $(12,73)$. Cold snare EMR is a widely used technique for polyps sized $<10 \mathrm{~mm}$, with emerging data that supports its use for polyps between 10 and $20 \mathrm{~mm}$ and even beyond $20 \mathrm{~mm}$, specially for serrated lesions (Figure 7) $(18,74-76)$. There are various solutions available for submucosal injections, with sterile normal saline being most frequently used. Other injectable solutions include saline with epinephrine, fibrin glue, hyaluronic acid, hydroxypropyl methylcellulose, succinylated gelatin and, glycerol (77-81). Vital dyes like methylene blue or non-vital dyes like indigo carmine help identify the deep muscular layer injury or perforation $(82,83)$. A meta-analysis of five randomized controlled studies showed a significant increase in en-bloc resection (OR 1.91, 95\% Cl: 1.11-3.29, $P=0.02$ ) and fewer residual lesions (OR 0.54, 95\% Cl: 0.32-0.91, $p$ $=0.02$ ) with viscous solutions compared to normal saline used for submucosal injection for EMR (84). The US multisociety task force on colorectal cancer recommends the use of a viscous injection solution (e.g., hydroxyethyl starch, Eleview ${ }^{\circledR}$ submucosal injectable composition, ORISE ${ }^{\mathrm{TM}}$ Gel Submucosal Lifting Agent, Boston Scientific) for lesions $\geq 20 \mathrm{~mm}$ to remove the lesion in a piecemeal fashion with less procedure time compared to normal saline (Figure 8). It also recommends the use of contrast agents, such as indigo carmine or methylene blue, in the submucosal injection solution to facilitate recognition of the submucosa from the mucosa and muscularis propria layers (85). Lesions are removed by snare excision either as en-bloc resection or piecemeal polypectomy, depending on size and morphology (Figure 9). A meta-analysis of 50 studies, including 6,442 patients with colorectal polyps $\geq 20 \mathrm{~mm}$ treated with EMR, showed an initial success rate of $92 \%$ for endoscopic resection, and only $8 \%$ of patients underwent surgery due to non-curative 

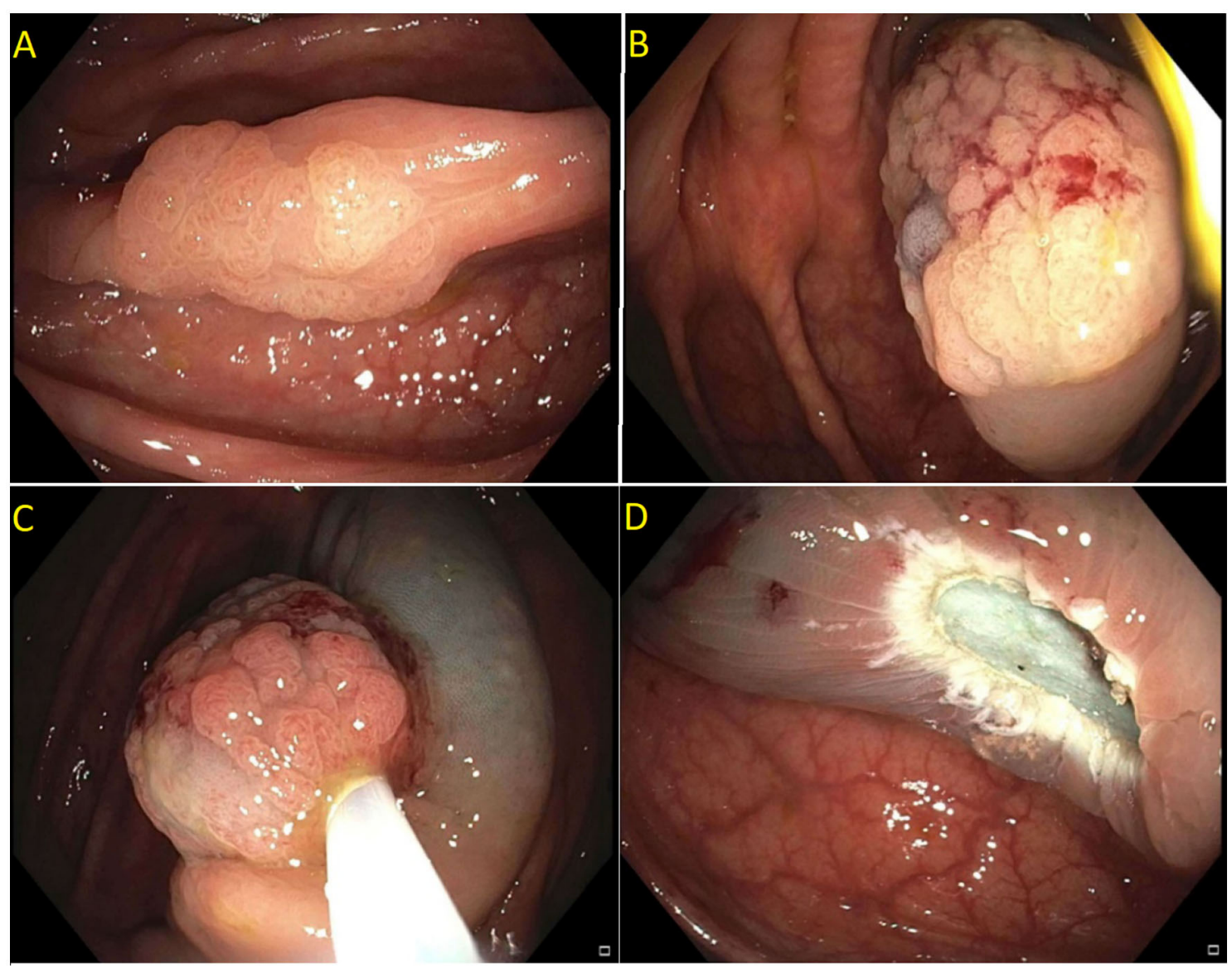

FIGURE 6 | (A,B) Paris 0-lla lesion, injected with methylene blue, size noted to be larger than originally suspected; (C,D) En-bloc endoscopic mucosal resection with blended coagulation current and a $20 \mathrm{~mm}$ snare.

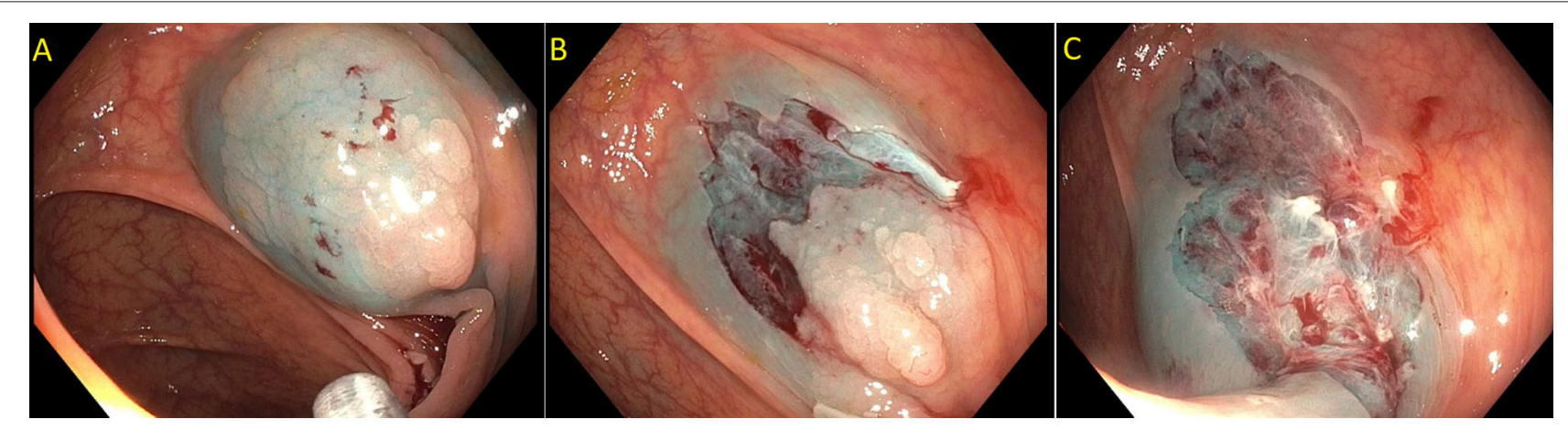

FIGURE 7 | (A) Sessile serrated lesion injected prior to resection to better define resection borders; (B,C) Sessile serrated lesion removed by dynamic submucosal injection and piecemeal cold endoscopic mucosal resection.

endoscopic resection. Endoscopic recurrence, perforation and bleeding occurred in 13.8, 1.5 and 6.5\%, respectively (86). Studies have shown that EMR is not only cost-effective than surgery; it has less morbidity and mortality also (Table 1). It should be considered the first line of treatment for patients with these sessile or lateral spreading large $(\geq 20 \mathrm{~mm})$ lesions $(60,87)$.
En-bloc resection is preferred over piecemeal polypectomy as it allows more accurate histological assessment. In cases of malignant polyps, it gives fundamental information on lateral and vertical margins. Deep submucosal invasion, defined as tumor involvement $\geq 1 \mathrm{~mm}(1,000 \mathrm{~mm}$, or SM3 on Kikuchi classification), is associated with a high risk of lymph node 


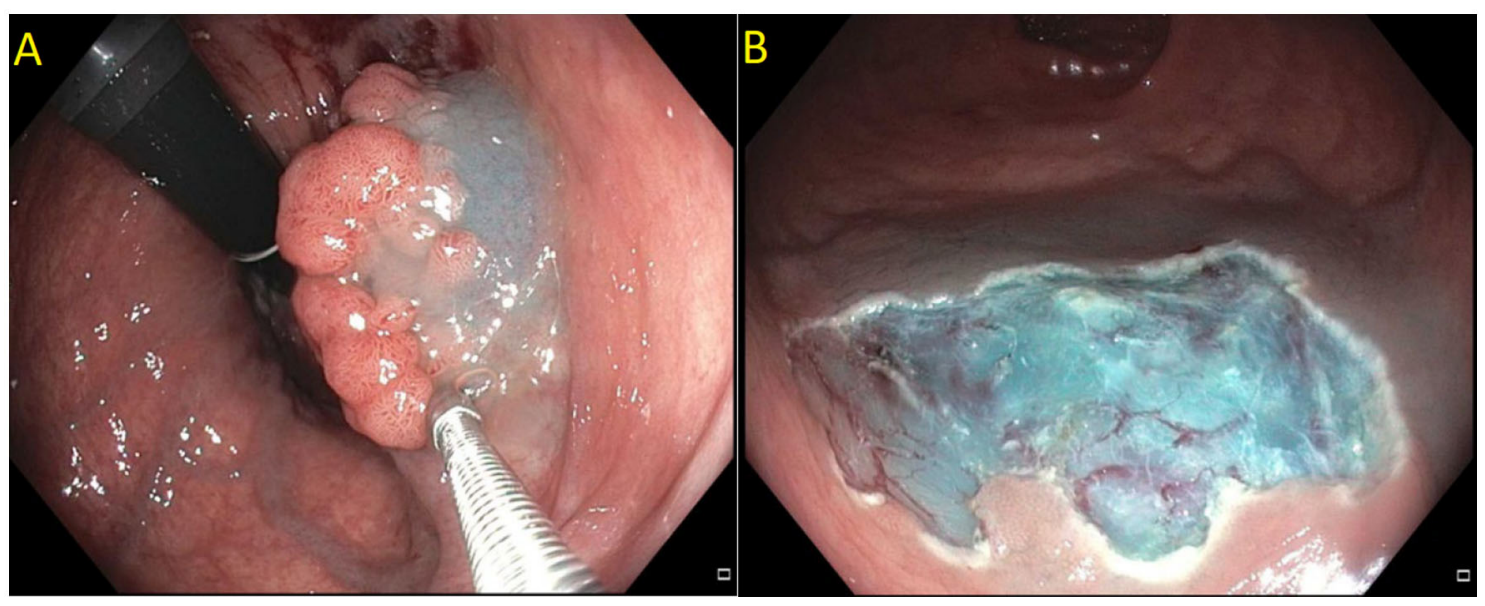

FIGURE 8 | (A) Submucosal injection using ORISE ${ }^{\mathrm{TM}}$ gel submucosal lifting agent (Boston Scientific). (B) Submucosa easily identify with indigocarmine non-vital stain.

metastasis and residual recurrence (10-18\%) (114). A metaanalysis of 33 studies showed the overall recurrence risk for EMR resection to be $15 \%$ (95\% $\mathrm{Cl} 12-19 \%)$. The recurrence rate was higher after piecemeal resection (20\%) than en-bloc resection (115). A multicenter prospective study of 1,000 successful EMR procedures for sessile or laterally spreading colonic lesions $\geq 20 \mathrm{~mm}$ in size showed an early recurrent/residual adenoma rate of $16 \%(95 \% \mathrm{Cl}: 13.6-18.7 \%)$ (116). Out of the total, $71.7 \%$ of these were diminutive, and $93.1 \%$ treated successfully using the endoscopic method. Lesions size $>40 \mathrm{~mm}$, use of argon plasma coagulation (APC) for treatment of incomplete polyp resections, and intraprocedural bleeding was identified as risk factors for these recurrent/residual adenomas (116). Consequently, surveillance endoscopy is recommended at 6 and at 16-18 months after piecemeal EMR to detect any recurrence (117). The US Multi-Society Task Force on Colorectal Cancer recommends using adjuvant thermal ablation at the margins of the polypectomy, even when there is no endoscopically visible polypoid tissue for treatment of micropolyp not visible by endoscopy (39). The most common modalities include APC or snare tip soft coagulation. Residual polypoid tissue within the polypectomy site is best treated by avulsing the residual polyp using hot forceps called as hot forceps avulsion technique (39).

Another technique, underwater EMR is also gaining in popularity. Different from conventional injection assisted EMR, where submucosal injection provides a cushion separating the submucosal layer form the muscularis propria (MP), no submucosal injection is performed during underwater EMR to raise the lesion. The polyp is submersed in water and the intraluminal air removed, removing colonic wall tension, and separating the mucosa from the MP. This prevents accidental muscle entrapment with the snare and helps with thermal dissipation, decreasing the risk of perforation during resection. Additional advantages of this technique is that it allows the capture of a larger mucosal surface area in the opened snare, increasing the chance of en-bloc resection without the use of a larger snare, and the resection is faster than compared to the conventional technique. The disadvantage of this technique is bleeding underwater during resection can obscure visualization $(118,119)$.

\section{Endoscopic Submucosal Dissection}

Endoscopic submucosal dissection (ESD) is an advanced form of polypectomy designed to resect large lesions in an en-bloc manner resulting in lower recurrence rates $(120,121)$. It was initially described in Japan for resection of early gastric cancer and now adopted to treat complex colorectal polyps (122, 123). ESD allows en-bloc resection of large superficial polyps, especially flat polyps, which would otherwise need piecemeal resection with EMR. A piecemeal resection by EMR lead to increased recurrent rates when compared to en-bloc ESD (124, 125). ESD involves a submucosal injection to achieve adequate submucosal lift and then circumferential incision of mucosa using an endoscopic knife, followed by submucosal dissection underneath the lesion above the muscularis propria (73, $117,126)$. ESD is time-consuming, labor-intensive, technically difficult, and has a higher risk of complications like bleeding or perforation $(71,117)$.

American Gastroenterology Association recommends ESD for colorectal lesions which are too large to ensure en bloc resection with EMR or at higher risk of containing cancer (125). Similarly, the European Society of Gastrointestinal Society recommends that ESD to be considered in patients with colonic and rectal lesions suspected to have a superficial submucosal invasion ( $\mathrm{sm} 1$ and sm2), which cannot be removed en-bloc by EMR technique (127). Lesions with suspicion for deep submucosal invasion (sm3) or muscualris propria invasion should be referred for surgical management. The greatest benefit of ESD is in rectal lesions. ESD offers a minimally invasive option with adequate $\mathrm{R} 0$ resection in selected early rectal cancers ( $\mathrm{T} 1$, where in cancer is restricted to the submucosa) with no high risk histologic features, ESD has also shown great results in the management of residual/recurrent tumors after EMR, tumors in patients with 

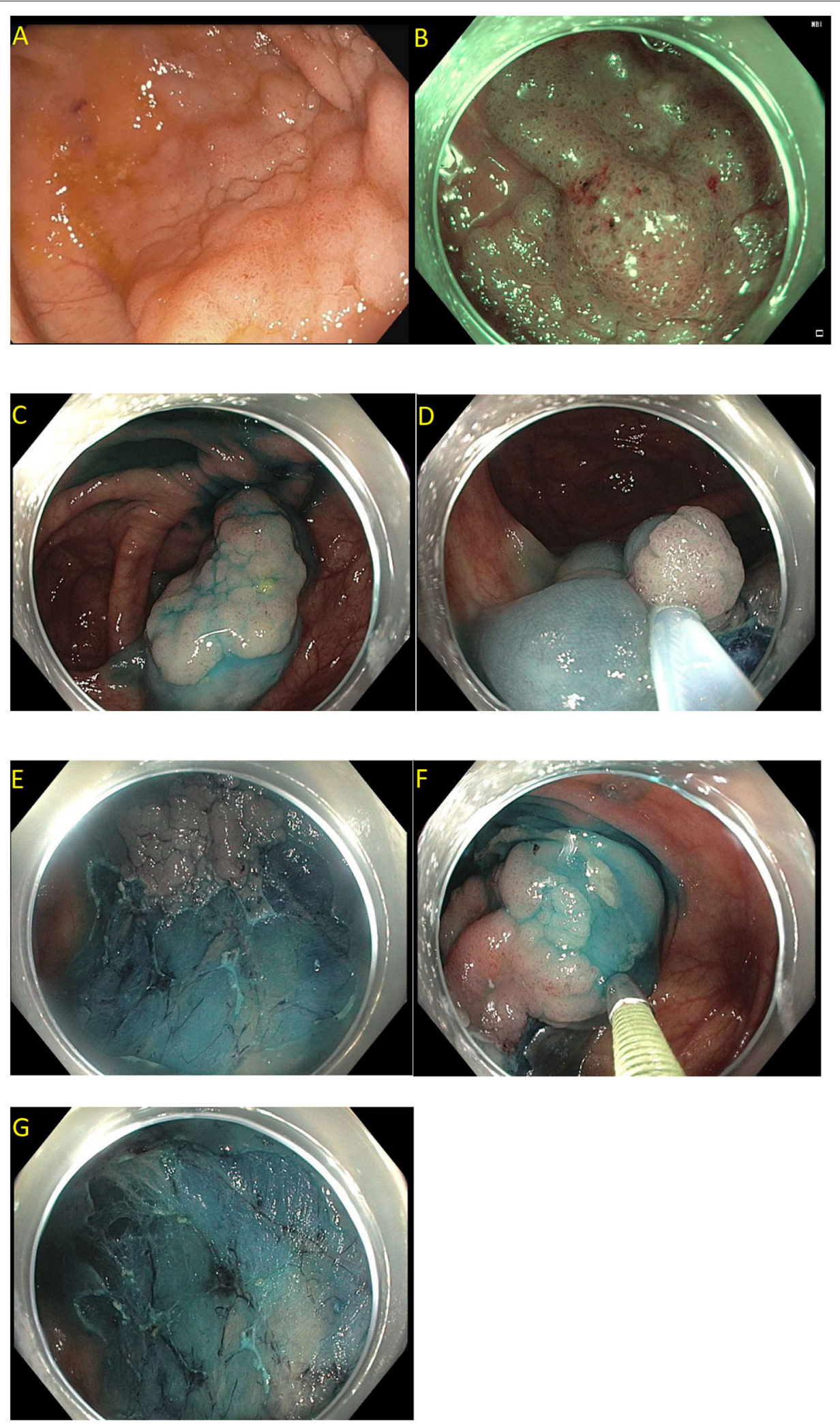

FIGURE 9 | Piecemeal endoscopic mucosal resection. (A) A 40 mm Paris 0-lla, granular lateral spreading lesion in the cecum seen on white light; (B) Same lesion seen under narrow band imaging; (C-G) Polyp removed by dynamic and piecemeal injection using a blended cutting current. The histology showed tubular adenoma. 
TABLE 1 | Endoscopic mucosal resection (EMR) for colon polyp studies with more than 100 patients.

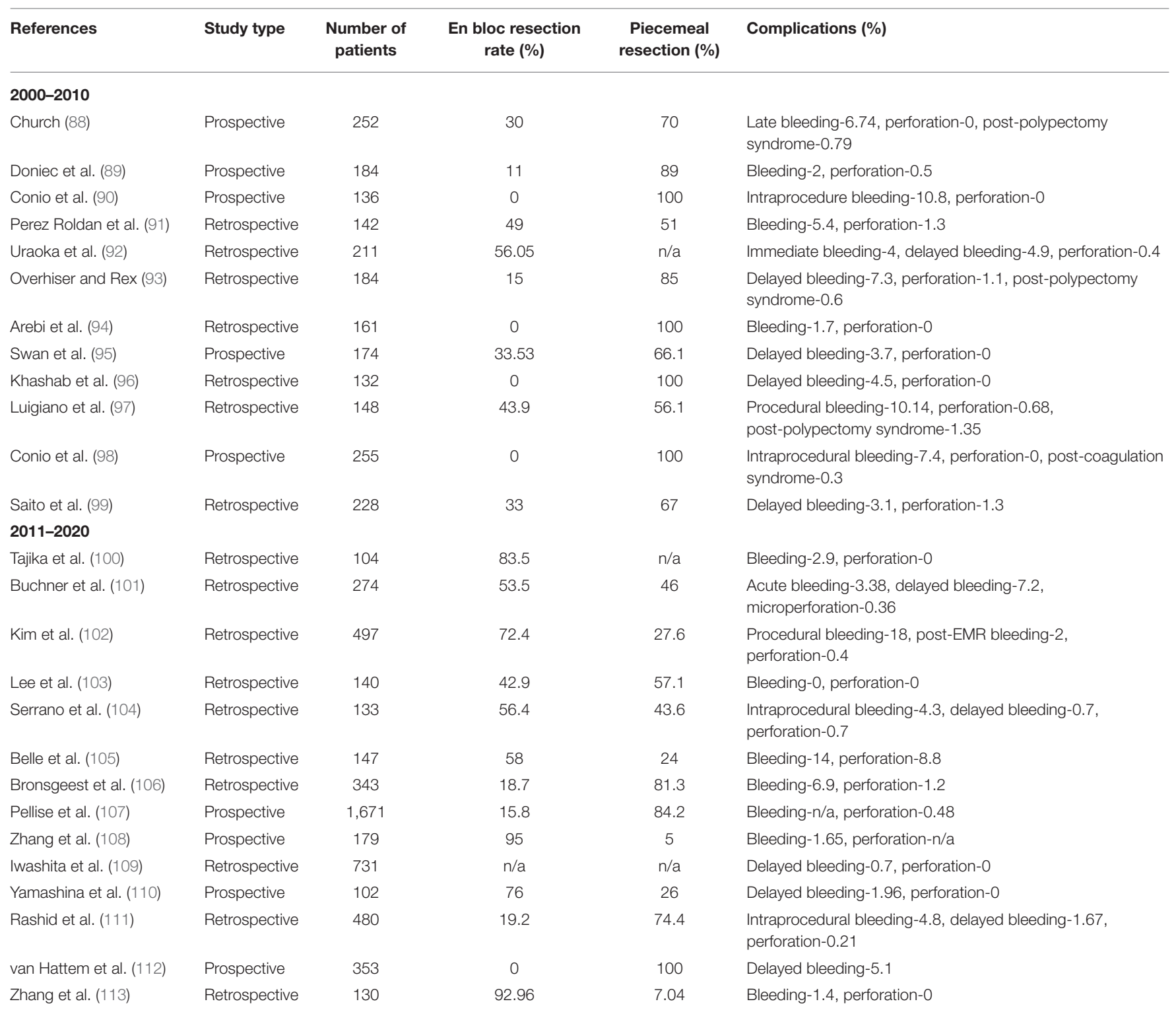

inflammatory bowel disease, and large colo-rectal polyps (128, 129).

There are 2 different techniques in ESD: the classical technique and the submucosal tunneling technique. The classical technique, with an initial circumferentially dissection around the polyp followed by dissection under the polyp and complete resection of the lesion. The submucosal tunnel leads to the creation of a pocket. The proximal end of the polyp is dissected initially and subsequently, the distal end is raised. The lateral end is not dissected at the beginning to avoid loss of injection fluid and the polyp raise is maintained. An inicision from the distal end is then used to create a tunnel and complete the dissection. Toward the end of the dissection, the lateral walls are dissected (130).

A meta-analysis of 14 studies evaluating the success of en-bloc resection of large colorectal polyps by ESD showed successful en-bloc resection in $84.91 \%$ (95\% Cl: 77.82-90.82) and complete cure en-bloc resection in $75.39 \%$ (95\% Cl: $66.69-$ 82.21) (131) (Table 2). Another systematic review and metaanalysis of 97 studies evaluating colorectal lesions resected using the ESD technique showed that the R0 resection rate was $82.9 \%(95 \% \mathrm{Cl}: 80.4-85.1 \%)$ and significantly higher in Asian countries than non-Asian countries (85.6 vs. $71.3 \%$ ). Similarly, the en-bloc resection rate was $91 \%$ (95\% $\mathrm{Cl} 89.2-$ 92.5\%), which was also significantly higher in Asian countries than non-Asian countries (93 vs. $81.2 \%$ ). The complication like recurrence at 12 months (2\%), delayed bleeding (2.7\%) and perforation (5.2\%) were significantly low (132). ESD is an established endoscopic resection method in Asian countries and being slowly adopted in Western countries with increasing practice in Europe over the last decade 
TABLE 2 | Endoscopic submucosal dissection (ESD) for colon polyp studies with more than 100 patients.

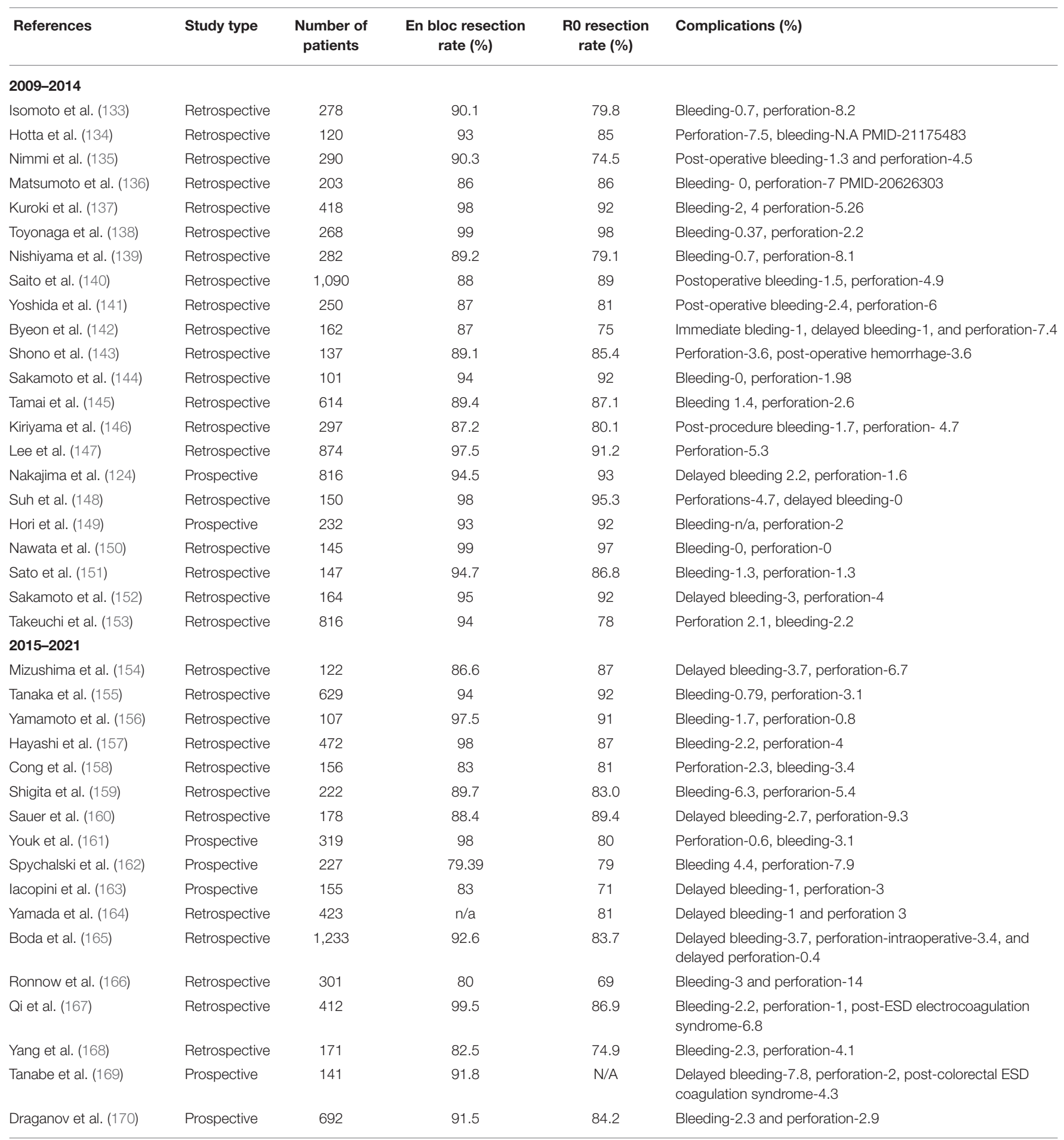

RO, Radical resection rate; Defined as dysplasia free vertical and lateral resection margins at histology.

and now in the United States, mainly in advanced tertiary centers (125).

A meta-analysis of 66 studies comparing EMR and ESD for colorectal lesions showed higher en bloc resection rate of 90.5\% with ESD compared to $62.8 \%$ with EMR (OR 0.18,
95\% CI 0.16-0.2) (171). Similar results were reported in other meta-analyses showing higher en bloc resection rates with ESD compared to $\operatorname{EMR}(99,172)$. There are several advancements in endoscopic tools which have made ESD less cumbersome. There are various colonic dissection knives (dual knife, dual-J 
knife, Hook knife, IT knife, IT-J knife, ERBE knife) and coagulation grasping forceps for co-agulation of bleeding. However, the traction tools are still lacking making it a challenging procedure (173).

\section{Hybrid ESD or Knife Assisted Snare Resection}

It combines ESD with snaring and thus simplifies the process of submucosal dissection. It is associated with shortening time to perform the procedure and complication rate, although it has lower en-bloc resection rates than typical ESD (174). It involves using an ESD knife to make a circumferential mucosal incision around the lesion, and then the targeted subepithelial lesion is grasped, retracted toward the lumen, followed by snare resection. Resection is aimed for en-bloc removal. This technique uses a standard snare, and needle-knives during $\operatorname{ESD}(12,130)$. It can also be used to resect scarred polyps (recurrence following previous EMR) (12).

Retrospective data was collected from a study in Japan conducted in patients with large colorectal polyps with size $>20 \mathrm{~mm}$ who underwent either ESD (for 137 lesions in 134 patients) or hybrid ESD (27 lesions in 26 patients). Results showed a shorter procedure time with hybrid ESD (108 \pm 59.5 vs. $122 \pm 72.2 \mathrm{~min}$ ) but lower en-bloc resection than the ESD group (66.7 vs. $94.2 \%)$. However, there were no significant differences in procedure time, in rates of en bloc resection or complication rates between the two groups (174).

In a meta-analysis, 97 studies evaluated standard technique, and 12 studies evaluated hybrid technique for colorectal lesions suspicious of superficial malignancy showed that R0 and enbloc resection rate of 60.6 and $68.4 \%$, respectively, for hybrid technique. It was significantly lower than the standard ESD technique with similar adverse event rates (132). Another recent meta-analysis of 16 studies with 751 patients who underwent hybrid ESD for large colorectal lesions showed an en-bloc resection rate and complication rate of $81.63 \%$ (95\% Cl: $72.07-$ $88.44)$ and $7.74 \%(95 \% \mathrm{Cl} 4.78-12.31)$, respectively. Subgroup analysis of conventional $(N=1,703)$ with hybrid $\operatorname{ESD}(N=497)$, procedure time was found to significantly shorter with hybrid ESD (mean difference $18.45 \mathrm{~min} ; p=0.003$ ), lower complication rate $(p=0.04)$, but it has lower en bloc resection rate $(p<$ $0.001)(175)$.

\section{Endoscopic Full-Thickness Resection}

This is another well-established advanced resection technique. The EFTR involves full-thickness plication of the bowel wall secured by an over-the-scope clip followed by bowel wall resection above the clip. Commercially available full-thickness resection device $\left(\right.$ FTRD $^{\circledR}$, Ovesco, Germany) is a single-step full-thickness device that combines a modified over-the-scope clip with an integrated snare (176). EFTR is for complex polyp that is not amenable to conventional endoscopic resection due to severe fibrosis and scarring, specific anatomical locations (close to a diverticulum or appendiceal orifice), and cases of incomplete resections. Lesions $<2.5 \mathrm{~cm}$ are suitable for this technique $(126,177)$. There is a small risk of appendicitis when lesions are resected close to the appendix and some risk of dehiscence due to OVESCO clip falling off the colonic mucosa thereby leading to peritonitis and sepsis. Most of the data is from small studies, so further large, randomized studies are needed, especially compared with other available endoscopic resection techniques (178-181).

\section{SPECIMEN HANDLING}

Pathological examination of specimens resected by EMR or ESD is a critical step and crucial for diagnosis of lymphatic spread and risk of metastasis. A clinical report with endoscopic information and a pinned formalin-fixed specimen with margins properly oriented by an endoscopist are necessary to start pathologic assessment $(182,183)$. The specimens are pinned onto a paraffin wax block and submerged in formaldehyde before submitting for the pathologic assessment to preserve tissue shape, size, and orientation. Knowledge about the appearance of the lesion is required to have the orientation of the specimen. To help orientation of en bloc resection specimens, these specimens are first flattened and fixed at their periphery with thin needles before immersion to formalin. The distance of cancerous tissue from the resection margin should be included for pedunculated specimens. Similarly, non-pedunculated cancerous lesion specimens should include the histology, depth of the lesion, cancerous involvement of the lateral and vertical margins, presence of tumor budding, degree of pathologic differentiation, and lymphatic and blood vessel involvement (39).

\section{COMPLICATIONS}

These advanced endoscopic techniques for the removal of complex polyps have an increased risk of various complications. Bleeding and perforation are two main complications associated with EMR and ESD procedures. Other complications include non-specific postprocedural pain, post polypectomy syndrome, residual tissue. It is very important for the endoscopists to prevent, early recognition and prompt management of these complications (Tables 1, 2).

\section{Bleeding}

Bleeding is the most common complication after the EMR procedure, reported in $0.7-24 \%$ of the cases. It can be classified into immediate post-polypectomy-IPPB (intraprocedural) or delayed post-polypectomy-DPPB (post-procedural) bleed (184). Intraprocedural bleeding has been reported in $11-22 \%$ of cases, and it can be controlled endoscopically, but it does prolong the procedure $(72,83,185)$. The risk factor for intraprocedural bleeding includes large polyps, tubulovillous or villous lesion, minimally elevated sessile polyps, limited operator experience with EMR. This bleeding is effectively managed during the procedure using snare tip soft coagulation, coagulation grasping forceps, or endoclips $(72,186)$. Postprocedural bleeding occurs hours to days after the procedure, and the rate of bleeding has been reported between 2 and 11\%, with clinically significant bleeding in $6 \%$ of the cases $(72,83,185)$. Risk factor for delayed bleeding includes lesions in the right colon, large lesions with size $\geq 40 \mathrm{~mm}$, age more than 75 years, antiplatelets or anticoagulants 
within seven days of procedure and intraprocedural bleeding (83, 187-189).

The bleeding rate after ESD ranges from 0 to $11.9 \%$ for upto 15 days post procedure. It can be classified into immediate (intraprocedural) or delayed (post-procedural) bleed $(190,191)$. A recent meta-analysis of 104 studies showed the rate of immediate and delayed major bleeding of $0.75 \%$ (95\% Cl: 0.31$1.8 \%$ ) and $2.1 \%$ (95\% Cl: 1.6-2.6\%), respectively, after ESD for colorectal lesions (192). Risk factors for delayed bleeding include the lesion's size, sessile type, the occurrence of intraprocedural bleeding, use of prior anti-thrombotic agents $(193,194)$. Recent studies have shown lesions in the cecum and rectum have a higher incidence of delayed bleeding after $\operatorname{ESD}(193,195,196)$.

Several randomized studies have evaluated the utility of clip closure after resection of large non-pedunculated colonic polyps (197-199). Results of these studies argue against the routine use of prophylactic clip placement after polypectomy. However, clip closure is recommended to prevent DPPB after resection of large colorectal lesion $\geq 20 \mathrm{~mm}$ in size and proximal to the splenic flexure (200). Closure of lesion $\geq 20 \mathrm{~mm}$ is further supported by a recent meta-analysis of 13 studies that showed that prophylactic clipping $(1.4 \%)$ was associated with a lower rate of delayed bleeding compared to no clipping (5.2\%) (pooled OR:0.24, 95\% Cl: 0.12-0.50) after the EMR procedure (201).

\section{Perforation}

Another potential complication after EMR and ESD is colonic perforation. The risk of perforation is low after EMR, with the reported risk of $1-2 \%$. In a meta-analysis of 50 studies, endoscopic perforation occurred in $1.5 \%$ (95\% Cl: $1.2-1.7 \%)$ of cases following EMR for colorectal polyps $\geq 20 \mathrm{~mm}$ (86). Risk factors include using larger diameters snares $(\geq 20 \mathrm{~mm})$, proximal location, bulky lesions, and cutting current. Perforation is more common following colorectal ESD, and the rate reported to be up to 3.3 to $10 \%(140,171,172,202-204)$. A meta-analysis of 66 studies comparing EMR and ESD for colorectal lesions, perforation rate was found to higher with ESD compared to EMR (4.8 vs. $0.9 \%, p<0.0001)$ (171). Similar results were reported in other meta-analyses showing higher perforation risk with ESD compared to $\operatorname{EMR}(99,172)$. A meta-analysis of 97 studies with colorectal lesions removed by standard ESD showed a perforation rate of 5.2\% (95\% Cl: 4.4-6.1\%). This meta-analysis also included 12 studies with colorectal lesions removed by hybrid ESD and showed a perforation rate of 4.8\% (95\% Cl: 2.4-9.1\%) (132). Risk factors for perforations during ESD include tumor size, location, submucosal fibrosis, and operators with limited experience (205, 206). Perforations are more in the ascending colon and cecum due to its thin wall $(207,208)$.

Deep muscle injury without overt perforations (Sydney classification Type 2-3) or small perforations (up to $10 \mathrm{~mm}$ ) recognized during colonoscopy can be managed endoscopically with through the scope clips. Surgery can be avoided for overt perforations (Type 4-5) up to $30 \mathrm{~mm}$ by using larger capacity over the scope clips (Ovesco ${ }^{\circledR}$, Endoscopy AG, Tübingen, Germany, or the Padlock Clip ${ }^{\circledR}$ Defect Closure System, Steris HC, OH, USA); however, it requires surgical intervention if recognized late or if there is overt contamination (83, 171, 190, 209,
210). In selected cases, endoscopic suturing devices (Overstitch Endoscopic Suturing System ${ }^{\mathrm{TM}}$, Austin, Texas, USA), which provide full thickness closure, have been used to close larger lesions (211).

\section{Post-polypectomy Syndrome}

Post polypectomy syndrome is an electrocoagulation injury to the bowel wall after endoscopic treatments, including conventional polypectomy, EMR, and ESD. Injury to the wall induces a transmural burn and localized peritonitis, which in turn causes serosal inflammation $(212,213)$. Incidence of post polypectomy syndrome varies from $1 \%$ after conventional polypectomy or EMR to $9 \%$ after ESD (212). The patient presents with abdominal pain, fever, tenderness, leukocytosis, elevated C-reactive protein after an endoscopic procedure like polypectomy, ESD, or EMR, without any obvious perforation on abdominal imaging like radiograph or computed tomography $(138,190,213)$. Most of these patients are successfully managed with conservative treatment, including bowel rest, broad-spectrum antibiotics, and hydration. Patients should be reevaluated for possible delayed perforation in case they are not showing improvement or getting worse with conservative management $(212,214,215)$.

\section{Stenosis}

Post-ESD stenosis is defined as narrowing through which a standard endoscope cannot be advanced (130). Fortunately, there are only a few studies describing post ESD stenosis after colorectal ESD. This is mostly seen when more than $75 \%$ of the circumferential lesion is resected. In a retrospective study of 822 patients who underwent colorectal ESD, $0.49 \%$ (4/822) of patients developed stenosis post-procedure. Post-ESD stenosis occurred in $11.1 \%$ of patients who underwent circumferential resection between $\geq 90$ and $100 \%$, and in $50 \%$ of patients who underwent $100 \%$ circumferential resection (216). Similarly, in another study of 69 patients with large rectal neoplasm that required $\geq 75$ $\%$ circumferential resection, $19.7 \%$ of the patients developed post-ESD rectal strictures. In the subgroup analysis, patients who underwent total circumferential ESD developed stricture in $71.4 \%$ of cases, and those who underwent $\geq 90 \%$ circumferential resection developed stricture in $43.8 \%$ of cases (217). These studies showed that $\geq 90 \%$ circumferential resection is a risk factor for stenosis after colorectal ESD. Most of these patients are managed by endoscopic balloon dilatation $(130,216,217)$.

\section{FUTURE DIRECTION}

The main challenges in performing ESD in the west have been higher prevalence of colorectal polyp requiring ESD, unlike in Japan where ESD is performed more in the stomach. There is more prevalence of obesity in the west, which makes the colon tortuous and thereby procedure technically challenging. The risk of procedure complications are higher due to thin colonic wall unlike the thick gastric wall. Therefore, there is a need for more advanced tools for polyp traction and post polypectomy defect closure to safely perform the procedure. In US, although there is increase interest in ESD for colorectal lesions, the adoption has been slow due to lack of dedicated training in ESD. 
One of the common traction approaches is the distal attachment (cap) attached at the endoscope's end, which helps move the lesion away and allows visualization of the dissection plane $(12,218)$. Various traction devices have been developed to facilitate faster ESD with a lower complication rate $(12,219)$. One simple method to achieve traction is to have a silk line (like a dental floss) tied to a hemostatic clip to the edge of the lesion and pulling the lesion proximally using the line away from the colonic wall to perform a safe dissection. It is a simple method; it does not require any novel equipment but requires the endoscope's reinsertion (220). Internal traction modifies the above method by attaching a micro-tech elastic band or ring, or nylon to a clip attached to the lesion and another clip to the opposite end. No reinsertion of the endoscope is required (221, 222). Another novel system consisting of an expandable working chamber with two independent instrument guides (LIG) has been used in the in vivo model to achieve safe and effective completion of ESD and submuscular dissection by improving visualization, access to the target tissue, and improving procedure time (223).

Another technique, thin endoscope-assisted ESD, allows traction in any direction where the second endoscope is inserted alongside the main endoscope. At present, this technique is limited to the distal sigmoid colon and rectum (224). Other techniques like a three-dimensional printed overtube system with two manipulator arms at the tip and magnetic traction methods have shown promising results in animal models $(225,226)$. Most of these techniques are not in mainstream use. Clip and string are commonly used in most ESD practices as they don't require any special equipment (12).

Post polypectomy defect closure post resection is another significant challenge especially in the right side colon. Di-Lumen or Lumendi is an accessory to the endoscope, which works like an overtube. This helps in reducing the loop in the colon thereby ensuring better stability with right side colon polyp resection and faster access to the lesion especially in the right side of the colon. The time for resection of large polyps in the right side of the colon has decreased by nearly $50 \%$ due to Lumendi. The overtube can then be used as a conduit to pass the Apollo overstitch. The overstitch can usually only reach the left side of the colon, but because of the reduced loop and the colon being less tortuous

\section{REFERENCES}

1. CDC. Colorectal (Colon) Cancer. CDC (2020). Available online at: https:// www.cdc.gov/cancer/colorectal/statistics/index.htm (accessed February 15, 2021).

2. Siegel RL, Miller KD, Goding Sauer A, Fedewa SA, Butterly LF, Anderson JC, et al. Colorectal cancer statistics, 2020. CA Cancer J Clin. (2020) 70:14564. doi: $10.3322 /$ caac. 21601

3. Cancer Research UK. Bowel Cancer Statistics. Cancer Research UK. Available online at: https://www.cancerresearchuk.org/health-professional/cancerstatistics/statistics-by-cancer-type/bowel-cancer\#heading-Zero (accessed February 15, 2021).

4. Perisetti A, Khan H, George NE, Yendala R, Rafiq A, Blakely S, et al. Colorectal cancer screening use among insured adults: is out-of-pocket cost a barrier to routine screening? World J Gastrointest Pharmacol Ther. (2018) 9:31-8. doi: 10.4292/wjgpt.v9.i4.31 and straight, it is now able to reach the right side of the colon for safe closure of the post polypectomy defect. The disadvantage in using an apollo overstitch is that the scope has to be removed, the suture has to be loaded and the scope again reinserted which can add to the already prolonged procedure time $(227,228)$. A novel suture device called endoscopic tack is now FDA approved and the post polypectomy defect can be safely closed without scope removal (229). In addition to the current colonic dissection knives, there is a new speed boat Knife (Creo Medical) which can help in simultaneous injection, dissection, and coagulation. This helps in speedy dissection and en-bloc resection (230).

\section{CONCLUSION}

Management strategies for complex polyp have evolved immensely over the last two decades and continue to do so. This is due to a better understanding of complex polyps' pathophysiology and advancement in technology, which led to the development of novel endoscopic tools and techniques and more effective management of complications. Whenever an endoscopist encounters a complex colorectal lesion, many patient-specific variables like age, comorbidities, use of anticoagulants and polyp-specific like lesion size, location, and malignancy risk should be considered before deciding to either resect or refer to an advanced endoscopist. Most premalignant lesions can be removed with advanced endoscopist techniques, but these procedures require an endoscopic expert in the field, a center with the appropriate equipment, and trained staff. Management of complex polyp with advanced endoscopic techniques like EMR, ESD, and hybrid approcahes will lead to decreased morbidity, mortality, and healthcare cost by decreasing the need for surgical interventions. This will prevent unnecessary morbid surgical procedures for benign lesions.

\section{AUTHOR CONTRIBUTIONS}

RM, MG, CU, AP, HG, and JE: conception and design. RM, MG, and JE: literature search. RM and MG: first draft. All authors critical revision, editing, and final approval.

5. Lieberman DA, Weiss DG, Harford WV, Ahnen DJ, Provenzale D, Sontag SJ, et al. Five-year colon surveillance after screening colonoscopy. Gastroenterology. (2007) 133:1077-85. doi: 10.1053/j.gastro.2007. 07.006

6. Winawer SJ, Zauber AG. The advanced adenoma as the primary target of screening. Gastrointest Endosc Clin N Am. (2002) 12:19. doi: 10.1016/S1052-5157(03)00053-9

7. Malki A, ElRuz RA, Gupta I, Allouch A, Vranic S, Al Moustafa AE. Molecular mechanisms of colon cancer progression and metastasis: recent insights and advancements. Int J Mol Sci. (2020) 22:130. doi: 10.3390/ijms22010130

8. Levin B, Lieberman DA, McFarland B, Andrews KS, Brooks D, Bond J, et al. Screening and surveillance for the early detection of colorectal cancer and adenomatous polyps, 2008: a joint guideline from the American cancer society, the US multi-society task force on colorectal cancer, and the American college of radiology. Gastroenterology. (2008) 134:157095. doi: 10.1053/j.gastro.2008.02.002 
9. Winawer SJ, Zauber AG, Ho MN, O’Brien MJ, Gottlieb LS, Sternberg SS, et al. Prevention of colorectal cancer by colonoscopic polypectomy. The national polyp study workgroup. N Engl J Med. (1993) 329:197781. doi: 10.1056/NEJM199312303292701

10. Zauber AG, Winawer SJ, O'Brien MJ, Lansdorp-Vogelaar I, van Ballegooijen M, Hankey BF, et al. Colonoscopic polypectomy and longterm prevention of colorectal-cancer deaths. N Engl J Med. (2012) 366:687-96. doi: 10.1056/NEJMoa1100370

11. Nishihara R, Wu K, Lochhead P, Morikawa T, Liao X, Qian ZR, et al. Longterm colorectal-cancer incidence and mortality after lower endoscopy. $N$ Eng J Med. (2013) 369:1095-105. doi: 10.1056/NEJMoa1301969

12. Longcroft-Wheaton G, Bhandari M, Alkandari A, Bhandari P. Recent advances in the management of large and complex colonic polyps. F1000Res. (2018) 7:304. doi: 10.12688/f1000research.12930.1

13. Crockett SD, Nagtegaal ID. Terminology, molecular features, epidemiology, and management of serrated colorectal neoplasia. Gastroenterology. (2019) 157:949-66.e4. doi: 10.1053/j.gastro.2019.06.041

14. Brenner H, Schrotz-King P, Holleczek B, Katalinic A, Hoffmeister M. Declining bowel cancer incidence and mortality in Germany: an analysis of time trends in the first ten years after the introduction of screening colonoscopy. Deutsches Ärzteblatt Int. (2016) 113:101. doi: 10.3238/arztebl.2016.0101

15. Jover R, Bretthauer M, Dekker E, Holme O, Kaminski MF, Loberg M, et al. Rationale and design of the European polyp surveillance (EPoS) trials. Endoscopy. (2016) 48:571-8. doi: 10.1055/s-0042-104116

16. Hewett DG. Colonoscopic polypectomy: current techniques and controversies. Gastroenterol Clin N Am. (2013) 42:44358. doi: 10.1016/j.gtc.2013.05.015

17. Gupta N, Bansal A, Rao D, Early DS, Jonnalagadda S, Wani $\mathrm{SB}$, et al. Prevalence of advanced histological features in diminutive and small colon polyps. Gastrointest Endosc. (2012) 75:1022-30. doi: 10.1016/j.gie.2012.01.020

18. Repici A, Hassan C, Vitetta E, Ferrara E, Manes G, Gullotti G, et al. Safety of cold polypectomy for $<10 \mathrm{~mm}$ polyps at colonoscopy: a prospective multicenter study. Endoscopy. (2012) 44:27-31. doi: 10.1055/s-0031-1291387

19. Mönkemüller K, Neumann H, Fry LC, Ivekovic H, Malfertheiner P. Polypectomy techniques for difficult colon polyps. Dig Dis. (2008) 26:3426. doi: 10.1159/000177020

20. Vormbrock K, Mönkemüller K. Difficult colon polypectomy. World J Gastrointest Endosc. (2012) 4:269-80. doi: 10.4253/wige.v4.i7.269

21. Jung M. The 'difficult' polyp: pitfalls for endoscopic removal. Dig Dis. (2012) 30 (Suppl. 2):74-80. doi: 10.1159/000341898

22. Hintze RE, Adler A, Veltzke W. Endoscopic resection of large colorectal adenomas: a combination of snare and laser ablation. Endoscopy. (1995) 27:665-70. doi: 10.1055/s-2007-1005784

23. Iishi $H$, Tatsuta $M$, Iseki $K$, Narahara $H$, Uedo $N$, Sakai $N$, et al. Endoscopic piecemeal resection with submucosal saline injection of large sessile colorectal polyps. Gastrointest Endosc. (2000) 51:697700. doi: $10.1067 /$ mge.2000.104652

24. Waye JD. Advanced Polypectomy. Gastrointest Endosc Clin N Am. (2005) 15:733-56. doi: 10.1016/j.giec.2005.08.004

25. Sanchez-Yague A, Kaltenbach T, Raju G, Soetikno R. Advanced endoscopic resection of colorectal lesions. Gastroenterol Clin. (2013) 42:459-77. doi: 10.1016/j.gtc.2013.05.012

26. Rex DK, Bond JH, Feld AD. Medical-legal risks of incident cancers after clearing colonoscopy. Am J Gastroenterol. (2001) 96:952-7. doi: 10.1111/j.1572-0241.2001.03677.x

27. Rutter MD, Nickerson C, Rees CJ, Patnick J, Blanks RG. Risk factors for adverse events related to polypectomy in the english bowel cancer screening programme. Endoscopy. (2014) 46:90-7. doi: 10.1055/s-0033-13 44987

28. Pohl H, Srivastava A, Bensen SP, Anderson P, Rothstein RI, Gordon $\mathrm{SR}$, et al. Incomplete polyp resection during colonoscopy-results of the complete adenoma resection (CARE) study. Gastroenterology. (2013) 144:74-80.el. doi: 10.1053/j.gastro.2012.09.043

29. Bourke MJ, Neuhaus H, Bergman JJ. Endoscopic submucosal dissection: indications and application in western endoscopy practice. Gastroenterology. (2018) 154:1887-900.e5. doi: 10.1053/j.gastro.2018.01.068
30. Overwater A, Kessels K, Elias SG, Backes Y, Spanier BWM, Seerden TCJ, et al. Endoscopic resection of high-risk T1 colorectal carcinoma prior to surgical resection has no adverse effect on long-term outcomes. Gut. (2018) 67:284-90. doi: 10.1136/gutjnl-2015-310961

31. Oh EH, Kim N, Hwang SW, Park SH, Yang D-H, Ye BD, et al. Comparison of long-term recurrence-free survival between primary surgery and endoscopic resection followed by secondary surgery in T1 colorectal cancer. Gastrointest Endosc. (2021) 94:394-404. doi: 10.1016/j.gie.2021.02.021

32. Shaukat A, Kaltenbach T, Dominitz JA, Robertson DJ, Anderson JC, Cruise M, et al. Endoscopic recognition and management strategies for malignant colorectal polyps: recommendations of the US multi-society task force on colorectal cancer. Am J Gastroenterol. (2020) 115:175167. doi: 10.14309/ajg.0000000000001013

33. Fuccio L, Repici A, Hassan C, Ponchon T, Bhandari P, Jover R, et al. Why attempt en bloc resection of non-pedunculated colorectal adenomas? A systematic review of the prevalence of superficial submucosal invasive cancer after endoscopic submucosal dissection. Gut. (2018) 67:146474. doi: 10.1136/gutjnl-2017-315103

34. Nusko G, Mansmann U, Altendorf-Hofmann A, Groitl H, Wittekind C, Hahn EG. Risk of invasive carcinoma in colorectal adenomas assessed by size and site. Int J Colorectal Dis. (1997) 12:267-71. doi: 10.1007/s003840050103

35. D'Amico F, Amato A, Iannone A, Trovato C, Romana C, Angeletti S, et al. Risk of covert submucosal cancer in patients with granular mixed laterally spreading tumors. Clin Gastroenterol Hepatol. (2020) 19:1395401. doi: $10.1016 /$ j.cgh.2020.07.024

36. Burgess NG, Hourigan LF, Zanati SA, Brown GJ, Singh R, Williams SJ, et al. Risk stratification for covert invasive cancer among patients referred for colonic endoscopic mucosal resection: a large multicenter cohort. Gastroenterology. (2017) 153:732-42.e1. doi: 10.1053/j.gastro.2017.05.047

37. Myung D-S, Kweon S-S, Lee J, Shin I-S, Kim S-W, Seo G-S, et al. Clinicopathological features of laterally spreading colorectal tumors and their association with advanced histology and invasiveness: an experience from Honam province of South Korea: a Honam association for the study of intestinal diseases (HASID). PLoS ONE. (2017) 12:e0184205. doi: 10.1371/journal.pone.0184205

38. Endoscopic Classification Review Group. Update on the Paris classification of superficial neoplastic lesions in the digestive tract. Endoscopy. (2005) 37:570-8. doi: 10.1055/s-2005-861352

39. Kaltenbach T, Anderson JC, Burke CA, Dominitz JA, Gupta S, Lieberman $\mathrm{D}$, et al. Endoscopic removal of colorectal lesions: recommendations by the US multi-society task force on colorectal cancer. Gastroenterology. (2020) 158:1095-129. doi: 10.1053/j.gastro.2019.12.018

40. Hewett DG, Kaltenbach T, Sano Y, Tanaka S, Saunders BP, Ponchon T, et al. Validation of a simple classification system for endoscopic diagnosis of small colorectal polyps using narrow-band imaging. Gastroenterology. (2012) 143:599-607.e1. doi: 10.1053/j.gastro.2012.05.006

41. Hayashi N, Tanaka S, Hewett DG, Kaltenbach TR, Sano Y, Ponchon $\mathrm{T}$, et al. Endoscopic prediction of deep submucosal invasive carcinoma: validation of the narrow-band imaging international colorectal endoscopic (NICE) classification. Gastrointest Endosc. (2013) 78:625-32. doi: 10.1016/j.gie.2013.04.185

42. Rastogi A, Keighley J, Singh V, Callahan P, Bansal A, Wani S, et al. High accuracy of narrow band imaging without magnification for the real-time characterization of polyp histology and its comparison with high-definition white light colonoscopy: a prospective study. Am J Gastroenterol. (2009) 104:2422-30. doi: 10.1038/ajg.2009.403

43. Zhou Q-J, Yang J-M, Fei B-Y, Xu Q-S, Wu W-Q, Ruan H-J. Narrow-band imaging endoscopy with and without magnification in diagnosis of colorectal neoplasia. World J Gastroenterol. (2011) 17:666-70. doi: 10.3748/wjg.v17.i5.666

44. Sumimoto K, Tanaka S, Shigita K, Hirano D, Tamaru Y, Ninomiya Y, et al. Clinical impact and characteristics of the narrow-band imaging magnifying endoscopic classification of colorectal tumors proposed by the Japan NBI expert team. Gastrointest Endosc. (2017) 85:81621. doi: $10.1016 /$ j.gie.2016.07.035

45. Tung SY, Wu CS, Su MY. Magnifying colonoscopy in differentiating neoplastic from nonneoplastic colorectal lesions. Am J Gastroenterol. (2001) 96:2628-32. doi: 10.1111/j.1572-0241.2001.04120.x 
46. Kikuchi R, Takano M, Takagi K, Fujimoto N, Nozaki R, Fujiyoshi $\mathrm{T}$, et al. Management of early invasive colorectal cancer. Risk of recurrence and clinical guidelines. Dis Colon Rectum. (1995) 38:128695. doi: 10.1007/BF02049154

47. Nascimbeni R, Burgart LJ, Nivatvongs S, Larson DR. Risk of lymph node metastasis in T1 carcinoma of the colon and rectum. Dis Colon Rectum. (2002) 45:200-6. doi: 10.1007/s10350-004-6147-7

48. Haggitt RC, Glotzbach RE, Soffer EE, Wruble LD. Prognostic factors in colorectal carcinomas arising in adenomas: implications for lesions removed by endoscopic polypectomy. Gastroenterology. (1985) 89:32836. doi: 10.1016/0016-5085(85)90333-6

49. Nivatvongs S, Rojanasakul A, Reiman HM, Dozois RR, Wolff BG, Pemberton $\mathrm{JH}$, et al. The risk of lymph node metastasis in colorectal polyps with invasive adenocarcinoma. Dis Colon Rectum. (1991) 34:3238. doi: 10.1007/BF02050592

50. Hashiguchi Y, Muro K, Saito Y, Ito Y, Ajioka Y, Hamaguchi T, et al. Japanese society for cancer of the colon and rectum (JSCCR) guidelines 2019 for the treatment of colorectal cancer. Int J Clin Oncol. (2020) 25:142. doi: 10.1007/s10147-019-01485-z

51. Shinagawa T, Tanaka T, Nozawa H, Emoto S, Murono K, Kaneko M, et al. Comparison of the guidelines for colorectal cancer in Japan, the USA and Europe. Ann Gastroenterol Surg. (2018) 2:6-12. doi: 10.1002/ags3.12047

52. Yoshii S, Nojima M, Nosho K, Omori S, Kusumi T, Okuda H, et al. Factors associated with risk for colorectal cancer recurrence after endoscopic resection of T1 tumors. Clin Gastroenterol Hepatol. (2014) 12:292302.e3. doi: 10.1016/j.cgh.2013.08.008

53. Bartel MJ, Brahmbhatt BS, Wallace MB. Management of colorectal T1 carcinoma treated by endoscopic resection from the Western perspective. Dig Endosc. (2016) 28:330-41. doi: 10.1111/den.12598

54. Vogel JD, Eskicioglu C, Weiser MR, Feingold DL, Steele SR. The American society of colon and rectal surgeons clinical practice guidelines for the treatment of colon cancer. Dis Colon Rectum. (2017) 60:9991017. doi: 10.1097/DCR.0000000000000926

55. Sidhu M, Tate DJ, Desomer L, Brown G, Hourigan LF, Lee EYT, et al. The size, morphology, site, and access score predicts critical outcomes of endoscopic mucosal resection in the colon. Endoscopy. (2018) 50:68492. doi: 10.1055/s-0043-124081

56. Sansone S, Ragunath K, Bianco MA, Manguso F, Beg S, Bagewadi A, et al. Clinical utility of the SMSA grading tool for the management of colonic neoplastic lesions. Dig Liver Dis. (2017) 49:518-22. doi: 10.1016/j.dld.2016.12.030

57. Gupta S, Miskovic D, Bhandari P, Dolwani S, McKaig B, Pullan R, et al. The 'SMSA' scoring system for determining the complexity of a polyp. Gut. (2011) 60 (Suppl. 1):A129. doi: 10.1136/gut.2011.239301.273

58. Peery AF, Cools KS, Strassle PD, McGill SK, Crockett SD, Barker $A$, et al. Increasing rates of surgery for patients with nonmalignant colorectal polyps in the United States. Gastroenterology. (2018) 154:135260.e3. doi: 10.1053/j.gastro.2018.01.003

59. van Nimwegen LJ, Moons LMG, Geesing JMJ, Arensman LR, Laclé M, Broeders I, et al. Extent of unnecessary surgery for benign rectal polyps in the Netherlands. Gastrointest Endosc. (2018) 87:562-70.e1. doi: 10.1016/j.gie.2017.06.027

60. Jayanna M, Burgess NG, Singh R, Hourigan LF, Brown GJ, Zanati SA, et al. Cost analysis of endoscopic mucosal resection vs surgery for large laterally spreading colorectal lesions. Clin Gastroenterol Hepatol. (2016) 14:271-8.e12. doi: 10.1016/j.cgh.2015.08.037

61. Peery AF, Shaheen NJ, Cools KS, Baron TH, Koruda M, Galanko JA, et al. Morbidity and mortality after surgery for nonmalignant colorectal polyps. Gastrointest Endosc. (2018) 87:243-50.e2. doi: 10.1016/j.gie.2017.0 3.1550

62. Atallah S, Albert M, Larach S. Transanal minimally invasive surgery: a giant leap forward. Surg Endosc. (2010) 24:22005. doi: 10.1007/s00464-010-0927-z

63. Probst A, Ebigbo A, Markl B, Schaller T, Anthuber M, Fleischmann $\mathrm{C}$, et al. Endoscopic submucosal dissection for early rectal neoplasia: experience from a European center. Endoscopy. (2017) 49:222-32. doi: 10.1055/s-0042-118449
64. Quaresima S, Balla A, Franceschilli L, La Torre M, Iafrate C, Shalaby M, et al. Transanal minimally invasive surgery for rectal lesions. JSLS. (2016) 20:e201600032. doi: 10.4293/JSLS.2016.00032

65. Dekkers N, Boonstra JJ, Moons LMG, Hompes R, Bastiaansen BA, Tuynman JB, et al. Transanal minimally invasive surgery (TAMIS) versus endoscopic submucosal dissection (ESD) for resection of nonpedunculated rectal lesions (TRIASSIC study): study protocol of a European multicenter randomised controlled trial. BMC Gastroenterol. (2020) 20:225. doi: 10.1186/s12876-020-01367-z

66. Gorgun E, Benlice C, Church JM. Does cancer risk in colonic polyps unsuitable for polypectomy support the need for advanced endoscopic resections? J Am Coll Surg. (2016) 223:478-84. doi: 10.1016/j.jamcollsurg.2016.05.018

67. Bertelson NL, Kalkbrenner KA, Merchea A, Dozois EJ, Landmann RG, De Petris G, et al. Colectomy for endoscopically unresectable polyps: how often is it cancer? Dis Colon Rectum. (2012) 55:11116. doi: 10.1097/DCR.0b013e3182695115

68. Shinya H, Wolff WI. Morphology, anatomic distribution and cancer potential of colonic polyps: an analysis of 7,000 polyps endoscopically removed. Ann Surg. (1979) 190:67983. doi: 10.1097/00000658-197912000-00001

69. O’Brien MJ, Winawer SJ, Zauber AG, Gottlieb LS, Sternberg SS, Diaz B, et al. The national polyp study: patient and polyp characteristics associated with high-grade dysplasia in colorectal adenomas. Gastroenterology. (1990) 98:371-9. doi: 10.1016/0016-5085(90)90827-N

70. Higaki S, Hashimoto S, Harada K, Nohara H, Saito Y, Gondo T, et al. Long-Term follow-up of large flat colorectal tumors resected endoscopically. Endoscopy. (2003) 35:845-9. doi: 10.1055/s-2003-42622

71. Herszényi L. The "difficult" colorectal polyps and adenomas: practical aspects. Dig Dis. (2019) 37:394-9. doi: 10.1159/000495694

72. Klein A, Bourke MJ. Advanced polypectomy and resection techniques. Gastrointest Endosc Clin N Am. (2015) 25:30333. doi: 10.1016/j.giec.2014.11.005

73. Pidala MJ, Cusick MV. The difficult colorectal polyp. Surg Clin North Am. (2017) 97:515-27. doi: 10.1016/j.suc.2017.01.003

74. Choksi N, Elmunzer BJ, Stidham RW, Shuster D, Piraka C. Cold snare piecemeal resection of colonic and duodenal polyps $\geq 1 \mathrm{~cm}$. Endosc Int Open. (2015) 3:E508-13. doi: 10.1055/s-0034-1392214

75. Mangira D, Cameron K, Simons K, Zanati S, LaNauze R, Raftopoulos S, et al. Cold snare piecemeal EMR of large sessile colonic polyps $\geq 20 \mathrm{~mm}$ (with video). Gastrointest Endosc. (2020) 91:1343-52. doi: 10.1016/j.gie.2019.12.051

76. Tutticci NJ, Hewett DG. Cold EMR of large sessile serrated polyps at colonoscopy (with video). Gastrointest Endosc. (2018) 87:837-42. doi: 10.1016/j.gie.2017.11.002

77. Fujishiro M, Yahagi N, Kashimura K, Mizushima Y, Oka M, Enomoto S, et al. Comparison of various submucosal injection solutions for maintaining mucosal elevation during endoscopic mucosal resection. Endoscopy. (2004) 36:579-83. doi: 10.1055/s-2004-814517

78. Feitoza AB, Gostout CJ, Burgart LJ, Burkert A, Herman LJ, Rajan E. Hydroxypropyl methylcellulose: a better submucosal fluid cushion for endoscopic mucosal resection. Gastrointestinal endoscopy. (2003) 57:417. doi: $10.1067 /$ mge.2003.25

79. Arezzo A, Pagano N, Romeo F, Delconte G, Hervoso C, Morino M, et al. Hydroxy-propyl-methyl-cellulose is a safe and effective lifting agent for endoscopic mucosal resection of large colorectal polyps. Surg Endosc. (2009) 23:1065-9. doi: 10.1007/s00464-008-0133-4

80. Yamamoto H, Yube T, Isoda N, Sato Y, Sekine Y, Higashizawa T, et al. A novel method of endoscopic mucosal resection using sodium hyaluronate. Gastrointest Endosc. (1999) 50:251-6. doi: 10.1016/S0016-5107(99)70234-8

81. Yamamoto $H$, Yahagi N, Oyama T, Gotoda T, Doi T, Hirasaki S, et al. Usefulness and safety of $0.4 \%$ sodium hyaluronate solution as a submucosal fluid "cushion" in endoscopic resection for gastric neoplasms: a prospective multicenter trial. Gastrointest Endosc. (2008) 67:8309. doi: 10.1016/j.gie.2007.07.039

82. Holt BA, Jayasekeran V, Sonson R, Bourke MJ. Topical submucosal chromoendoscopy defines the level of resection in colonic EMR and may 
improve procedural safety (with video). Gastrointest Endosc. (2013) 77:94953. doi: 10.1016/j.gie.2013.01.021

83. Hwang JH, Konda V, Abu Dayyeh BK, Chauhan SS, Enestvedt BK, FujiiLau LL, et al. Endoscopic mucosal resection. Gastrointest Endosc. (2015) 82:215-26. doi: 10.1016/j.gie.2015.05.001

84. Yandrapu H, Desai M, Siddique S, Vennalganti P, Vennalaganti S, Parasa S, et al. Normal saline solution versus other viscous solutions for submucosal injection during endoscopic mucosal resection: a systematic review and meta-analysis. Gastrointest Endosc. (2017) 85:693-9. doi: 10.1016/j.gie.2016.12.003

85. Kaltenbach T, Anderson JC, Burke CA, Dominitz JA, Gupta S, Lieberman $\mathrm{D}$, et al. Endoscopic removal of colorectal lesions: recommendations by the US multi-society task force on colorectal cancer. Am J Gastroenterol. (2020) 115:435-64. doi: 10.14309/ajg.0000000000000555

86. Hassan C, Repici A, Sharma P, Correale L, Zullo A, Bretthauer M, et al. Efficacy and safety of endoscopic resection of large colorectal polyps: a systematic review and meta-analysis. Gut. (2016) 65:80620. doi: 10.1136/gutjnl-2014-308481

87. Ahlenstiel G, Hourigan LF, Brown G, Zanati S, Williams SJ, Singh R, et al. Actual endoscopic versus predicted surgical mortality for treatment of advanced mucosal neoplasia of the colon. Gastrointest Endosc. (2014) 80:668-76. doi: $10.1016 /$ j.gie.2014.04.015

88. Church JM. Experience in the endoscopic management of large colonic polyps. ANZ J Surg. (2003) 73:98895. doi: 10.1046/j.1445-2197.2003.t01-23-.x

89. Doniec JM, Lohnert MS, Schniewind B, Bokelmann F, Kremer B, Grimm H. Endoscopic removal of large colorectal polyps: prevention of unnecessary surgery? Dis Colon Rectum. (2003) 46:340-8. doi: 10.1007/s10350-004-6553-x

90. Conio M, Repici A, Demarquay JF, Blanchi S, Dumas R, Filiberti R. EMR of large sessile colorectal polyps. Gastrointest Endosc. (2004) 60:23441. doi: 10.1016/S0016-5107(04)01567-6

91. Perez Roldan F, Gonzalez Carro P, Legaz Huidobro ML, Villafanez Garcia MC, Soto Fernandez S, de Pedro Esteban A, et al. Endoscopic resection of large colorectal polyps. Rev Esp Enferm Dig. (2004) 96:3647. doi: $10.4321 / \mathrm{S} 1130-01082004000100006$

92. Uraoka T, Fujii T, Saito Y, Sumiyoshi T, Emura F, Bhandari P, et al. Effectiveness of glycerol as a submucosal injection for EMR. Gastrointest Endosc. (2005) 61:736-40. doi: 10.1016/S0016-5107(05)00321-4

93. Overhiser AJ, Rex DK. Work and resources needed for endoscopic resection of large sessile colorectal polyps. Clin Gastroenterol Hepatol. (2007) 5:10769. doi: 10.1016/j.cgh.2007.04.022

94. Arebi N, Swain D, Suzuki N, Fraser C, Price A, Saunders BP. Endoscopic mucosal resection of 161 cases of large sessile or flat colorectal polyps. Scand J Gastroenterol. (2007) 42:859-66. doi: 10.1080/00365520601137280

95. Swan MP, Bourke MJ, Alexander S, Moss A, Williams SJ. Large refractory colonic polyps: is it time to change our practice? A prospective study of the clinical and economic impact of a tertiary referral colonic mucosal resection and polypectomy service (with videos). Gastrointest Endosc. (2009) 70:1128-36. doi: 10.1016/j.gie.2009.05.039

96. Khashab M, Eid E, Rusche M, Rex DK. Incidence and predictors of "late" recurrences after endoscopic piecemeal resection of large sessile adenomas. Gastrointest Endosc. (2009) 70:344-9. doi: 10.1016/j.gie.2008.10.037

97. Luigiano C, Consolo P, Scaffidi MG, Strangio G, Giacobbe G, Alibrandi A, et al. Endoscopic mucosal resection for large and giant sessile and flat colorectal polyps: a single-center experience with long-term follow-up. Endoscopy. (2009) 41:829-35. doi: 10.1055/s-0029-1215091

98. Conio M, Blanchi S, Repici A, Ruggeri C, Fisher DA, Filiberti R. Cap-assisted endoscopic mucosal resection for colorectal polyps. Dis Colon Rectum. (2010) 53:919-27. doi: 10.1007/DCR.0b013e3181d95a54

99. Saito Y, Fukuzawa M, Matsuda T, Fukunaga S, Sakamoto T, Uraoka T, et al. Clinical outcome of endoscopic submucosal dissection versus endoscopic mucosal resection of large colorectal tumors as determined by curative resection. Surg Endosc. (2010) 24:343-52. doi: 10.1007/s00464-009-0562-8

100. Tajika M, Niwa Y, Bhatia V, Kondo S, Tanaka T, Mizuno N, et al. Comparison of endoscopic submucosal dissection and endoscopic mucosal resection for large colorectal tumors. Eur J Gastroenterol Hepatol. (2011) 23:10429. doi: 10.1097/MEG.0b013e32834aa47b
101. Buchner AM, Guarner-Argente C, Ginsberg GG. Outcomes of EMR of defiant colorectal lesions directed to an endoscopy referral center. Gastrointest Endosc. (2012) 76:255-63. doi: 10.1016/j.gie.2012.02.060

102. Kim HH, Kim JH, Park SJ, Park MI, Moon W. Risk factors for incomplete resection and complications in endoscopic mucosal resection for lateral spreading tumors. Dig Endosc. (2012) 24:259-66. doi: 10.1111/j.1443-1661.2011.01232.x

103. Lee EJ, Lee JB, Lee SH, Youk EG. Endoscopic treatment of large colorectal tumors: comparison of endoscopic mucosal resection, endoscopic mucosal resection-precutting, and endoscopic submucosal dissection. Surg Endosc. (2012) 26:2220-30. doi: 10.1007/s00464-012-2164-0

104. Serrano M, Mao de Ferro S, Fidalgo P, Lage P, Chaves P, Dias Pereira A. Endoscopic mucosal resection of superficial colorectal neoplasms: review of 140 procedures. Acta Med Port. (2012) 25:288-96.

105. Belle S, Haase L, Pilz LR, Post S, Ebert M, Kaehler G. Recurrence after endoscopic mucosal resection-therapy failure? Int J Colorectal Dis. (2014) 29:209-15. doi: 10.1007/s00384-013-1783-9

106. Bronsgeest K, Huisman JF, Langers A, Boonstra JJ, Schenk BE, de Vos Tot Nederveen Cappel WH, et al. Safety of endoscopic mucosal resection (EMR) of large non-pedunculated colorectal adenomas in the elderly. Int J Colorectal Dis. (2017) 32:1711-7. doi: 10.1007/s00384-017-2892-7

107. Pellise M, Burgess NG, Tutticci N, Hourigan LF, Zanati SA, Brown GJ, et al. Endoscopic mucosal resection for large serrated lesions in comparison with adenomas: a prospective multicentre study of 2000 lesions. Gut. (2017) 66:644-53. doi: 10.1136/gutjnl-2015-310249

108. Zhang Q, Gao P, Han B, Xu J, Shen Y. Polypectomy for complete endoscopic resection of small colorectal polyps. Gastrointest Endosc. (2018) 87:73340. doi: 10.1016/j.gie.2017.06.010

109. Iwashita H, Takedatsu H, Murao H, Funakoshi S, Kuniki Y, Matsuoka S, et al. Safety and efficacy of cold polypectomy compared to endoscopic mucosal resection and hot biopsy polypectomy. Scand J Gastroenterol. (2019) 54:678-83. doi: 10.1080/00365521.2019.1613444

110. Yamashina T, Uedo N, Akasaka T, Iwatsubo T, Nakatani Y, Akamatsu T, et al. Comparison of underwater vs conventional endoscopic mucosal resection of intermediate-size colorectal polyps. Gastroenterology. (2019) 157:45161.e2. doi: 10.1053/j.gastro.2019.04.005

111. Rashid MU, Khetpal N, Zafar H, Ali S, Idrisov E, Du Y, et al. Colon mucosal neoplasia referred for endoscopic mucosal resection: recurrence of adenomas and prediction of submucosal invasion. World J Gastrointest Endosc. (2020) 12:198-211. doi: 10.4253/wjge.v12.i7.198

112. van Hattem WA, Shahidi N, Vosko S, Hartley I, Britto K, Sidhu $\mathrm{M}$, et al. Piecemeal cold snare polypectomy versus conventional endoscopic mucosal resection for large sessile serrated lesions: a retrospective comparison across two successive periods. Gut. (2020) 70:1691-7. doi: 10.1136/gutjnl-2020-321753

113. Zhang Z, Xia Y, Cui H, Yuan X, Wang C, Xie J, et al. Underwater versus conventional endoscopic mucosal resection for small size non-pedunculated colorectal polyps: a randomized controlled trial : (UEMR vs. CEMR for small size non-pedunculated colorectal polyps). BMC Gastroenterol. (2020) 20:311. doi: 10.1186/s12876-020-01457-y

114. Choi JY, Jung S-A, Shim K-N, Cho WY, Keum B, Byeon J-S, et al. Metaanalysis of predictive clinicopathologic factors for lymph node metastasis in patients with early colorectal carcinoma. J Korean Med Sci. (2015) 30:398406. doi: $10.3346 / \mathrm{jkms} .2015 .30 .4 .398$

115. Belderbos TD, Leenders M, Moons LM, Siersema PD. Local recurrence after endoscopic mucosal resection of nonpedunculated colorectal lesions: systematic review and meta-analysis. Endoscopy. (2014) 46:388-402. doi: 10.1055/s-0034-1364970

116. Moss A, Williams SJ, Hourigan LF, Brown G, Tam W, Singh R, et al. Long-term adenoma recurrence following wide-field endoscopic mucosal resection (WF-EMR) for advanced colonic mucosal neoplasia is infrequent: results and risk factors in 1000 cases from the Australian colonic EMR (ACE) study. Gut. (2015) 64:57-65. doi: 10.1136/gutjnl-2013-3 05516

117. Thirumurthi S, Raju GS. How to deal with large colorectal polyps: snare, endoscopic mucosal resection, and endoscopic submucosal dissection; resect or refer? Curr Opin Gastroenterol. (2016) 32:26-31. doi: 10.1097/MOG.0000000000000228 
118. Amato A, Radaelli F, Spinzi G. Underwater endoscopic mucosal resection: the third way for en bloc resection of colonic lesions? United Euro Gastroenterol J. (2016) 4:595-8. doi: 10.1177/2050640615617635

119. Wang AY, Flynn MM, Patrie JT, Cox DG, Bleibel W, Mann JA, et al. Underwater endoscopic mucosal resection of colorectal neoplasia is easily learned, efficacious, and safe. Surg Endosc. (2014) 28:134854. doi: 10.1007/s00464-013-3297-5

120. Wang J, Zhang X-H, Ge J, Yang C-M, Liu J-Y, Zhao S-L. Endoscopic submucosal dissection vs endoscopic mucosal resection for colorectal tumors: a meta-analysis. World J Gastroenterol. (2014) 20:8282-7. doi: 10.3748/wjg.v20.i25.8282

121. Sakamoto T, Mori G, Yamada M, Kinjo Y, So E, Abe S, et al. Endoscopic submucosal dissection for colorectal neoplasms: a review. World J Gastroenterol. (2014) 20:16153-8. doi: 10.3748/wjg.v20.i43.16153

122. Hirao M, Masuda K, Asanuma T, Naka H, Noda K, Matsuura K, et al. Endoscopic resection of early gastric cancer and other tumors with local injection of hypertonic saline-epinephrine. Gastrointest Endosc. (1988) 34:264-9. doi: 10.1016/S0016-5107(88)71327-9

123. Yamamoto H, Yahagi N, Oyama T. Mucosectomy in the colon with endoscopic submucosal dissection. Endoscopy. (2005) 37:764-8. doi: 10.1055/s-2005-870166

124. Nakajima T, Saito Y, Tanaka S, Iishi H, Kudo SE, Ikematsu H, et al. Current status of endoscopic resection strategy for large, early colorectal neoplasia in Japan. Surg Endosc. (2013) 27:3262-70. doi: 10.1007/s00464-013-2903-x

125. Draganov PV, Wang AY, Othman MO, Fukami N. AGA institute clinical practice update: endoscopic submucosal dissection in the United States. Clin Gastroenterol Hepatol. (2019) 17:16-25 e1. doi: 10.1016/j.cgh.2018.07.041

126. Dumoulin FL, Hildenbrand R. Endoscopic resection techniques for colorectal neoplasia: current developments. World J Gastroenterol. (2019) 25:300-7. doi: 10.3748/wjg.v25.i3.300

127. Ferlitsch M, Moss A, Hassan C, Bhandari P, Dumonceau JM, Paspatis G, et al. Colorectal polypectomy and endoscopic mucosal resection (EMR): European society of gastrointestinal endoscopy (esge) clinical guideline. Endoscopy. (2017) 49:270-97. doi: 10.1055/s-0043-102569

128. Jung DH, Youn YH, Kim JH, Park H. Endoscopic submucosal dissection for colorectal lateral spreading tumors larger than $10 \mathrm{~cm}$ : is it feasible? Gastrointest Endosc. (2015) 81:614-20. doi: 10.1016/j.gie.2014.09.001

129. Iacopini F, Saito Y, Yamada M, Grossi C, Rigato P, Costamagna G, et al. Curative endoscopic submucosal dissection of large nonpolypoid superficial neoplasms in ulcerative colitis (with videos). Gastrointest Endosc. (2015) 82:734-8. doi: 10.1016/j.gie.2015.02.052

130. Maple JT, Abu Dayyeh BK, Chauhan SS, Hwang JH, Komanduri S, Manfredi M, et al. Endoscopic submucosal dissection. Gastrointest Endosc. (2015) 81:1311-25. doi: 10.1016/j.gie.2014.12.010

131. Puli SR, Kakugawa Y, Saito Y, Antillon D, Gotoda T, Antillon MR. Successful complete cure en-bloc resection of large nonpedunculated colonic polyps by endoscopic submucosal dissection: a meta-analysis and systematic review. Ann Surg Oncol. (2009) 16:2147-51. doi: 10.1245/s10434-009-0520-7

132. Fuccio L, Hassan C, Ponchon T, Mandolesi D, Farioli A, Cucchetti A, et al. Clinical outcomes after endoscopic submucosal dissection for colorectal neoplasia: a systematic review and meta-analysis. Gastrointest Endosc. (2017) 86:74-86.e17. doi: 10.1016/j.gie.2017.02.024

133. Isomoto $\mathrm{H}$, Nishiyama $\mathrm{H}$, Yamaguchi $\mathrm{N}$, Fukuda $\mathrm{E}$, Ishii $\mathrm{H}$, Ikeda $\mathrm{K}$, et al. Clinicopathological factors associated with clinical outcomes of endoscopic submucosal dissection for colorectal epithelial neoplasms. Endoscopy. (2009) 41:679-83. doi: 10.1055/s-0029-1214979

134. Hotta K, Oyama T, Shinohara T, Miyata Y, Takahashi A, Kitamura Y, et al. Learning curve for endoscopic submucosal dissection of large colorectal tumors. Dig Endosc. (2010) 22:302-6. doi: 10.1111/j.1443-1661.2010.01005.x

135. Niimi K, Fujishiro M, Kodashima S, Goto O, Ono S, Hirano K, et al. Longterm outcomes of endoscopic submucosal dissection for colorectal epithelial neoplasms. Endoscopy. (2010) 42:723-9. doi: 10.1055/s-0030-1255675

136. Matsumoto A, Tanaka S, Oba S, Kanao H, Oka S, Yoshihara M, et al. Outcome of endoscopic submucosal dissection for colorectal tumors accompanied by fibrosis. Scand J Gastroenterol. (2010) 45:132937. doi: 10.3109/00365521.2010.495416

137. Kuroki Y, Hoteya S, Mitani T, Yamashita S, Kikuchi D, Fujimoto A, et al. Endoscopic submucosal dissection for residual/locally recurrent lesions after endoscopic therapy for colorectal tumors. J Gastroenterol Hepatol. (2010) 25:1747-53. doi: 10.1111/j.1440-1746.2010.06331.x

138. Toyonaga T, Man-i M, Fujita T, East JE, Nishino E, Ono W, et al. Retrospective study of technical aspects and complications of endoscopic submucosal dissection for laterally spreading tumors of the colorectum. Endoscopy. (2010) 42:714-22. doi: 10.1055/s-0030-1255654

139. Nishiyama H, Isomoto H, Yamaguchi N, Fukuda E, Ikeda K, Ohnita K, et al. Endoscopic submucosal dissection for colorectal epithelial neoplasms. Dis Colon Rectum. (2010) 53:161-8. doi: 10.1007/DCR.0b013e3181b78cb6

140. Saito Y, Uraoka T, Yamaguchi Y, Hotta K, Sakamoto N, Ikematsu H, et al. A prospective, multicenter study of 1111 colorectal endoscopic submucosal dissections (with video). Gastrointest Endosc. (2010) 72:121725. doi: 10.1016/j.gie.2010.08.004

141. Yoshida N, Naito $\mathrm{Y}$, Kugai M, Inoue K, Wakabayashi N, Yagi $\mathrm{N}$, et al. Efficient hemostatic method for endoscopic submucosal dissection of colorectal tumors. World J Gastroenterol. (2010) 16:4180-6. doi: 10.3748/wjg.v16.i33.4180

142. Byeon JS, Yang DH, Kim KJ, Ye BD, Myung SJ, Yang SK, et al. Endoscopic submucosal dissection with or without snaring for colorectal neoplasms. Gastrointest Endosc. (2011) 74:1075-83. doi: 10.1016/j.gie.2011.03.1248

143. Shono T, Ishikawa K, Ochiai Y, Nakao M, Togawa O, Nishimura M, et al. Feasibility of endoscopic submucosal dissection: a new technique for en bloc resection of a large superficial tumor in the colon and rectum. Int J Surg Oncol. (2011) 2011:948293. doi: 10.1155/2011/948293

144. Sakamoto T, Saito Y, Fukunaga S, Nakajima T, Matsuda T. Learning curve associated with colorectal endoscopic submucosal dissection for endoscopists experienced in gastric endoscopic submucosal dissection. Dis Colon Rectum. (2011) 54:1307-12. doi: 10.1097/DCR.0b013e3182282ab0

145. Tamai N, Saito Y, Sakamoto T, Nakajima T, Matsuda T, Tajiri H. Safety and efficacy of colorectal endoscopic submucosal dissection in elders: clinical and follow-up outcomes. Int J Colorectal Dis. (2012) 27:14939. doi: 10.1007/s00384-012-1514-7

146. Kiriyama S, Saito Y, Yamamoto S, Soetikno R, Matsuda T, Nakajima T, et al. Comparison of endoscopic submucosal dissection with laparoscopic-assisted colorectal surgery for early-stage colorectal cancer: a retrospective analysis. Endoscopy. (2012) 44:1024-30. doi: 10.1055/s-0032-1310259

147. Lee EJ, Lee JB, Lee SH, Kim DS, Lee DH, Lee DS, et al. Endoscopic submucosal dissection for colorectal tumors-1,000 colorectal ESD cases: one specialized institute's experiences. Surg Endosc. (2013) 27:31-9. doi: 10.1007/s00464-012-2403-4

148. Suh JP, Youk EG, Lee EJ, Lee JB, Lee IT, Lee DS, et al. Endoscopic submucosal dissection for nonpedunculated submucosal invasive colorectal cancer: is it feasible? Eur J Gastroenterol Hepatol. (2013) 25:10519. doi: 10.1097/MEG.0b013e328361dd39

149. Hori K, Uraoka T, Harada K, Higashi R, Kawahara Y, Okada $\mathrm{H}$, et al. Predictive factors for technically difficult endoscopic submucosal dissection in the colorectum. Endoscopy. (2014) 46:862-70. doi: 10.1055/s-0034-1377205

150. Nawata Y, Homma K, Suzuki Y. Retrospective study of technical aspects and complications of endoscopic submucosal dissection for large superficial colorectal tumors. Dig Endosc. (2014) 26:552-5. doi: 10.1111/den.12217

151. Sato K, Ito $S$, Kitagawa $T$, Kato $M$, Tominaga $K$, Suzuki $T$, et al. Factors affecting the technical difficulty and clinical outcome of endoscopic submucosal dissection for colorectal tumors. Surg Endosc. (2014) 28:295965. doi: 10.1007/s00464-014-3558-y

152. Sakamoto T, Sato C, Makazu M, Sekiguchi M, Mori G, Yamada M, et al. Short-term outcomes of colorectal endoscopic submucosal dissection performed by trainees. Digestion. (2014) 89:37-42. doi: 10.1159/0003 56215

153. Takeuchi Y, Iishi H, Tanaka S, Saito Y, Ikematsu H, Kudo SE, et al. Factors associated with technical difficulties and adverse events of colorectal endoscopic submucosal dissection: retrospective exploratory factor analysis of a multicenter prospective cohort. Int J Colorectal Dis. (2014) 29:127584. doi: 10.1007/s00384-014-1947-2

154. Mizushima T, Kato M, Iwanaga I, Sato F, Kubo K, Ehira N, et al. Technical difficulty according to location, and risk factors for perforation, in endoscopic submucosal dissection of colorectal tumors. Surg Endosc. (2015) 29:133-9. doi: 10.1007/s00464-014-3665-9 
155. Tanaka S, Toyonaga T, Morita Y, Hoshi N, Ishida T, Ohara Y, et al. Feasibility and safety of endoscopic submucosal dissection for large colorectal tumors. Surg Laparosc Endosc Percutan Tech. (2015) 25:2238. doi: 10.1097/SLE.0000000000000135

156. Yamamoto K, Hayashi S, Saiki H, Indo N, Nakabori T, Yamamoto $\mathrm{M}$, et al. Endoscopic submucosal dissection for large superficial colorectal tumors using the "clip-flap method". Endoscopy. (2015) 10:262-5. doi: 10.1055/s-0034-1390739

157. Hayashi Y, Shinozaki S, Sunada K, Sato H, Miura Y, Ino Y, et al. Efficacy and safety of endoscopic submucosal dissection for superficial colorectal tumors more than $50 \mathrm{~mm}$ in diameter. Gastrointest Endosc. (2016) 83:6027. doi: 10.1016/j.gie.2015.08.037

158. Cong ZJ, Hu LH, Ji JT, Xing JJ, Shan YQ, Li ZS, et al. A long-term follow-up study on the prognosis of endoscopic submucosal dissection for colorectal laterally spreading tumors. Gastrointest Endosc. (2016) 83:8007. doi: 10.1016/j.gie.2015.08.043

159. Shigita K, Oka S, Tanaka S, Sumimoto K, Hirano D, Tamaru Y, et al. Long-term outcomes after endoscopic submucosal dissection for superficial colorectal tumors. Gastrointest Endosc. (2017) 85:54653. doi: 10.1016/j.gie.2016.07.044

160. Sauer M, Hildenbrand R, Oyama T, Sido B, Yahagi N, Dumoulin FL. Endoscopic submucosal dissection for flat or sessile colorectal neoplasia > 20 mm: a European single-center series of 182 cases. Endosc Int Open. (2016) 4:E895-900. doi: 10.1055/s-0042-111204

161. Youk EG, Sohn DK, Hong CW, Lee SD, Han KS, Kim BC, et al. Early outcomes of endoscopic submucosal dissection for colorectal neoplasms according to clinical indications. Dis Colon Rectum. (2016) 59:40310. doi: 10.1097/DCR.0000000000000549

162. Spychalski M, Skulimowski A, Dziki A, Saito Y. Colorectal endoscopic submucosal dissection (ESD) in the West - when can satisfactory results be obtained? A single-operator learning curve analysis. Scand J Gastroenterol. (2017) 52:1442-52. doi: 10.1080/00365521.2017.1379557

163. Iacopini F, Saito Y, Bella A, Gotoda T, Rigato P, Elisei W, et al. Colorectal endoscopic submucosal dissection: predictors and neoplasm-related gradients of difficulty. Endosc Int Open. (2017) 5:E839-46. doi: 10.1055/s-0043-113566

164. Yamada M, Saito Y, Takamaru H, Sasaki H, Yokota T, Matsuyama Y, et al. Long-term clinical outcomes of endoscopic submucosal dissection for colorectal neoplasms in 423 cases: a retrospective study. Endoscopy. (2017) 49:233-42. doi: 10.1055/s-0042-124366

165. Boda K, Oka S, Tanaka S, Nagata S, Kunihiro M, Kuwai T, et al. Clinical outcomes of endoscopic submucosal dissection for colorectal tumors: a large multicenter retrospective study from the hiroshima GI endoscopy research group. Gastrointest Endosc. (2018) 87:714-22. doi: 10.1016/j.gie.2017.05.051

166. Ronnow CF, Uedo N, Toth E, Thorlacius H. Endoscopic submucosal dissection of 301 large colorectal neoplasias: outcome and learning curve from a specialized center in Europe. Endosc Int Open. (2018) 6:E13408. doi: 10.1055/a-0733-3668

167. Qi Z-P, Shi Q, Liu J-Z, Yao L-Q, Xu M-D, Cai S-L, et al. Efficacy and safety of endoscopic submucosal dissection for submucosal tumors of the colon and rectum. Gastrointest Endosc. (2018) 87:540-8.el. doi: 10.1016/j.gie.2017.09.027

168. Yang D, Aihara H, Perbtani YB, Wang AY, Aadam AA, Tomizawa Y, et al. Safety and efficacy of endoscopic submucosal dissection for rectal neoplasia: a multicenter North American experience. Endosc Int Open. (2019) 7:E171422. doi: 10.1055/a-1010-5663

169. Tanabe H, Higurashi T, Takatsu T, Misawa N, Yoshihara T, Goto S, et al. Effects of colorectal endoscopic submucosal dissection on postoperative abdominal symptoms: a prospective observational study. Surg Endosc. (2022) 36:314-20. doi: 10.1007/s00464-020-08278-w

170. Draganov PV, Aihara H, Karasik MS, Ngamruengphong S, Aadam AA, Othman MO, et al. Endoscopic submucosal dissection In North America: a large prospective multicenter study. Gastroenterology. (2021) 160:231727.e2. doi: 10.1053/j.gastro.2021.02.036

171. De Ceglie A, Hassan C, Mangiavillano B, Matsuda T, Saito Y, Ridola L, et al. Endoscopic mucosal resection and endoscopic submucosal dissection for colorectal lesions: a systematic review. Crit Rev Oncol Hematol. (2016) 104:138-55. doi: 10.1016/j.critrevonc.2016.06.008
172. Fujiya M, Tanaka K, Dokoshi T, Tominaga M, Ueno N, Inaba Y, et al. Efficacy and adverse events of EMR and endoscopic submucosal dissection for the treatment of colon neoplasms: a meta-analysis of studies comparing EMR and endoscopic submucosal dissection. Gastrointest Endosc. (2015) 81:583-95. doi: 10.1016/j.gie.2014.07.034

173. Choi HS, Chun HJ. Accessory devices frequently used for endoscopic submucosal dissection. Clin Endosc. (2017) 50:22433. doi: 10.5946/ce.2017.070

174. Okamoto K, Muguruma N, Kagemoto K, Mitsui Y, Fujimoto D, Kitamura S, et al. Efficacy of hybrid endoscopic submucosal dissection (ESD) as a rescue treatment in difficult colorectal ESD cases. Dig Endosc. (2017) 29 (Suppl. 2):45-52. doi: 10.1111/den. 12863

175. McCarty TR, Bazarbashi AN, Thompson CC, Aihara H. Hybrid endoscopic submucosal dissection (ESD) compared with conventional ESD for colorectal lesions: a systematic review and meta-analysis. Endoscopy. (2020) 53:1048-58. doi: 10.1055/a-1266-1855

176. Schurr MO, Baur FE, Krautwald M, Fehlker M, Wehrmann M, Gottwald $\mathrm{T}$, et al. Endoscopic full-thickness resection and clip defect closure in the colon with the new FTRD system: experimental study. Surg Endosc. (2015) 29:2434-41. doi: 10.1007/s00464-014-3923-x

177. Hossain E, Alkandari A, Bhandari P. Future of endoscopy: brief review of current and future endoscopic resection techniques for colorectal lesions. Dig Endosc. (2020) 32:503-11. doi: 10.1111/den.13475

178. Vitali F, Naegel A, Siebler J, Neurath MF, Rath T. Endoscopic full-thickness resection with an over-the-scope clip device (FTRD) in the colorectum: results from a university tertiary referral center. Endosc Int Open. (2018) 6:E98-e103. doi: 10.1055/s-0043-124079

179. Aepli P, Criblez D, Baumeler S, Borovicka J, Frei R. Endoscopic full thickness resection (EFTR) of colorectal neoplasms with the full thickness resection device (FTRD): clinical experience from two tertiary referral centers in Switzerland. United Euro Gastroenterol J. (2018) 6:46370. doi: $10.1177 / 2050640617728001$

180. Richter-Schrag HJ, Walker C, Thimme R, Fischer A. [Full thickness resection device (FTRD). Experience and outcome for benign neoplasms of the rectum and colon]. Chirurg. (2016) 87:316-25. doi: 10.1007/s00104-015-0091-z

181. Schmidt A, Beyna T, Schumacher B, Meining A, Richter-Schrag HJ, Messmann $\mathrm{H}$, et al. Colonoscopic full-thickness resection using an over-thescope device: a prospective multicentre study in various indications. Gut. (2018) 67:1280-9. doi: 10.1136/gutjnl-2016-313677

182. Mojtahed A, Shimoda T. Proper pathologic preparation and assessment of endoscopic mucosal resection and endoscopic submucosal dissection specimens. Techn Gastrointest Endosc. (2011) 13:95-9. doi: 10.1016/j.tgie.2011.02.007

183. Geramizadeh B, Owen DA. Handling and pathology reporting of gastrointestinal endoscopic mucosal resection. Middle East J Dig Dis. (2017) 9:5-11. doi: 10.15171/mejdd.2016.45

184. Gallegos-Orozco JF, Gurudu SR. Complex colon polypectomy. Gastroenterol Hepatol. (2010) 6:375-82.

185. Burgess NG, Metz AJ, Williams SJ, Singh R, Tam W, Hourigan LF, et al. Risk factors for intraprocedural and clinically significant delayed bleeding after wide-field endoscopic mucosal resection of large colonic lesions. Clin Gastroenterol Hepatol. (2014) 12:651-61.e3. doi: 10.1016/j.cgh.2013. 09.049

186. Fahrtash-Bahin F, Holt BA, Jayasekeran V, Williams SJ, Sonson R, Bourke MJ. Snare tip soft coagulation achieves effective and safe endoscopic hemostasis during wide-field endoscopic resection of large colonic lesions (with videos). Gastrointest Endosc. (2013) 78:158-63.e1. doi: 10.1016/j.gie.2013.02.030

187. Metz AJ, Bourke MJ, Moss A, Williams SJ, Swan MP, Byth K. Factors that predict bleeding following endoscopic mucosal resection of large colonic lesions. Endoscopy. (2011) 43:506-11. doi: 10.1055/s-0030-1256346

188. van der Star S, Moons LMG, Ter Borg F, van Bergeijk JD, Geesing JMJ, Groen JN, et al. Management of delayed bleeding after endoscopic mucosal resection of large colorectal polyps: a retrospective multi-center cohort study. Endosc Int Open. (2020) 8:E1052-E60. doi: 10.1055/a-1192-3816

189. Albeniz E, Fraile M, Ibanez B, Alonso-Aguirre P, Martinez-Ares D, Soto S, et al. A scoring system to determine risk of delayed bleeding after endoscopic mucosal resection of large colorectal lesions. Clin Gastroenterol Hepatol. (2016) 14:1140-7. doi: 10.1016/j.cgh.2016.03.021 
190. Tanaka S, Kashida H, Saito Y, Yahagi N, Yamano H, Saito S, et al. JGES guidelines for colorectal endoscopic submucosal dissection/endoscopic mucosal resection. Dig Endosc. (2015) 27:417-34. doi: 10.1111/den. 12456

191. Yamamoto K, Michida T, Nishida T, Hayashi S, Naito M, Ito T. Colorectal endoscopic submucosal dissection: recent technical advances for safe and successful procedures. World J Gastrointest Endosc. (2015) 7:111428. doi: 10.4253/wjge.v7.i14.1114

192. Akintoye E, Kumar N, Aihara H, Nas H, Thompson CC. Colorectal endoscopic submucosal dissection: a systematic review and meta-analysis. Endosc Int Open. (2016) 4:E1030-E44. doi: 10.1055/s-0042-114774

193. Okamoto K, Watanabe T, Komeda Y, Kono T, Takashima K, Okamoto A, et al. Risk factors for postoperative bleeding in endoscopic submucosal dissection of colorectal tumors. Oncology. (2017) 93 (Suppl. 1):3542. doi: $10.1159 / 000481228$

194. Ogasawara N, Yoshimine T, Noda H, Kondo Y, Izawa S, Shinmura T, et al. Clinical risk factors for delayed bleeding after endoscopic submucosal dissection for colorectal tumors in Japanese patients. Eur J Gastroenterol Hepatol. (2016) 28:1407-14. doi: 10.1097/MEG.0000000000000723

195. Terasaki M, Tanaka S, Shigita K, Asayama N, Nishiyama S, Hayashi $\mathrm{N}$, et al. Risk factors for delayed bleeding after endoscopic submucosal dissection for colorectal neoplasms. Int J Colorectal Dis. (2014) 29:87782. doi: 10.1007/s00384-014-1901-3

196. Suzuki S, Chino A, Kishihara T, Uragami N, Tamegai Y, Suganuma $\mathrm{T}$, et al. Risk factors for bleeding after endoscopic submucosal dissection of colorectal neoplasms. World J Gastroenterol. (2014) 20:1839-45. doi: 10.3748/wjg.v20.i7.1839

197. Albéniz E, Álvarez MA, Espinós JC, Nogales O, Guarner C, Alonso $\mathrm{P}$, et al. Clip closure after resection of large colorectal lesions with substantial risk of bleeding. Gastroenterology. (2019) 157:1213-21.e4. doi: 10.1053/j.gastro.2019.07.037

198. Feagins LA, Smith AD, Kim D, Halai A, Duttala S, Chebaa B, et al. Efficacy of prophylactic hemoclips in prevention of delayed post-polypectomy bleeding in patients with large colonic polyps. Gastroenterology. (2019) 157:96776.e1. doi: 10.1053/j.gastro.2019.05.003

199. Pohl H, Grimm IS, Moyer MT, Hasan MK, Pleskow D, Elmunzer BJ, et al. Clip closure prevents bleeding after endoscopic resection of large colon polyps in a randomized trial. Gastroenterology. (2019) 157:97784.e3. doi: 10.1053/j.gastro.2019.03.019

200. Liaquat H, Rohn E, Rex DK. Prophylactic clip closure reduced the risk of delayed postpolypectomy hemorrhage: experience in 277 clipped large sessile or flat colorectal lesions and 247 control lesions. Gastrointest Endosc. (2013) 77:401-7. doi: 10.1016/j.gie.2012.10.024

201. Ayoub F, Westerveld D, Forde J, Draganov P, Yang D. Effect of prophylactic clip placement following endoscopic mucosal resection of large colorectal lesions on delayed polypectomy bleeding: a meta-analysis. World $J$ Gastroenterol. (2019) 25:2251-63. doi: 10.3748/wjg.v25.i18.2251

202. Tanaka S, Terasaki M, Kanao H, Oka S, Chayama K. Current status and future perspectives of endoscopic submucosal dissection for colorectal tumors. Dig Endosc. (2012) 24 (Suppl. 1):73-9. doi: 10.1111/j.1443-1661.2012.01252.x

203. Oka S, Tanaka S, Kanao H, Ishikawa H, Watanabe T, Igarashi M, et al. Current status in the occurrence of postoperative bleeding, perforation and residual/local recurrence during colonoscopic treatment in Japan. Dig Endosc. (2010) 22:376-80. doi: 10.1111/j.1443-1661.2010.01016.x

204. Pimentel-Nunes P, Dinis-Ribeiro M, Ponchon T, Repici A, Vieth M, De Ceglie A, et al. Endoscopic submucosal dissection: European society of gastrointestinal endoscopy (ESGE) guideline. Endoscopy. (2015) 47:82954. doi: 10.1055/s-0034-1392882

205. Kim ES, Cho KB, Park KS, Lee KI, Jang BK, Chung WJ, et al. Factors predictive of perforation during endoscopic submucosal dissection for the treatment of colorectal tumors. Endoscopy. (2011) 43:5738. doi: 10.1055/s-0030-1256339

206. Hong SN, Byeon JS, Lee BI, Yang DH, Kim J, Cho KB, et al. Prediction model and risk score for perforation in patients undergoing colorectal endoscopic submucosal dissection. Gastrointest Endosc. (2016) 84:98108. doi: 10.1016/j.gie.2015.12.011
207. Takamaru H, Saito Y, Yamada M, Tsuruki ES, Kinjo Y, Otake Y, et al. Clinical impact of endoscopic clip closure of perforations during endoscopic submucosal dissection for colorectal tumors. Gastrointest Endosc. (2016) 84:494-502.e1. doi: 10.1016/j.gie.2016.01.014

208. Lee EJ, Lee JB, Choi YS, Lee SH, Lee DH, Kim DS, et al. Clinical risk factors for perforation during endoscopic submucosal dissection (ESD) for largesized, nonpedunculated colorectal tumors. Surg Endosc. (2012) 26:158794. doi: 10.1007/s00464-011-2075-5

209. Pissas D, Ypsilantis E, Papagrigoriadis S, Hayee B, Haji A. Endoscopic management of iatrogenic perforations during endoscopic mucosal resection (EMR) and endoscopic submucosal dissection (ESD) for colorectal polyps: a case series. Therap Adv Gastroenterol. (2015) 8:176-81. doi: 10.1177/1756283X15576844

210. Turan AS, Ultee G, Van Geenen EJM, Siersema PD. Clips for managing perforation and bleeding after colorectal endoscopic mucosal resection. Expert Rev Med Devices. (2019) 16:493501. doi: 10.1080/17434440.2019.1618707

211. Kantsevoy SV, Bitner M, Mitrakov AA, Thuluvath PJ. Endoscopic suturing closure of large mucosal defects after endoscopic submucosal dissection is technically feasible, fast, and eliminates the need for hospitalization (with videos). Gastrointest Endosc. (2014) 79:503-7. doi: 10.1016/j.gie.2013. 10.051

212. Hirasawa K, Sato C, Makazu M, Kaneko H, Kobayashi R, Kokawa A, et al. Coagulation syndrome: delayed perforation after colorectal endoscopic treatments. World J Gastrointest Endosc. (2015) 7:105561. doi: 10.4253/wjge.v7.i12.1055

213. Arimoto J, Higurashi T, Kato S, Fuyuki A, Ohkubo H, Nonaka T, et al. Risk factors for post-colorectal endoscopic submucosal dissection (ESD) coagulation syndrome: a multicenter, prospective, observational study. Endosc Int Open. (2018) 6:E342-e9. doi: 10.1055/s-0044-101451

214. Cha JM, Lim KS, Lee SH, Joo YE, Hong SP, Kim TI, et al. Clinical outcomes and risk factors of post-polypectomy coagulation syndrome: a multicenter, retrospective, case-control study. Endoscopy. (2013) 45:2027. doi: 10.1055/s-0032-1326104

215. Hong MJ, Kim JH, Lee SY, Sung IK, Park HS, Shim CS. Prevalence and clinical features of coagulation syndrome after endoscopic submucosal dissection for colorectal neoplasms. Dig Dis Sci. (2015) 60:211-6. doi: 10.1007/s10620-014-3484-9

216. Hayashi T, Kudo SE, Miyachi H, Sakurai T, Ishigaki T, Yagawa Y, et al. Management and risk factor of stenosis after endoscopic submucosal dissection for colorectal neoplasms. Gastrointest Endosc. (2017) 86:35869. doi: 10.1016/j.gie.2016.11.032

217. Ohara Y, Toyonaga T, Tanaka S, Ishida T, Hoshi N, Yoshizaki T, et al. Risk of stricture after endoscopic submucosal dissection for large rectal neoplasms. Endoscopy. (2016) 48:62-70. doi: 10.1055/s-0034-1392514

218. Harlow C, Sivananthan A, Ayaru L, Patel K, Darzi A, Patel N. Endoscopic submucosal dissection: an update on tools and accessories. Ther Adv Gastrointest Endosc. (2020) 13:2631774520957220. doi: 10.1177/2631774520 957220

219. Xia M, Zhou Y, Yu J, Chen W, Huang X, Liao J. Short-term outcomes of traction-assisted versus conventional endoscopic submucosal dissection for superficial gastrointestinal neoplasms: a systematic review and metaanalysis of randomized controlled studies. World J Surg Oncol. (2019) 17:94. doi: 10.1186/s12957-019-1639-Z

220. Ota R, Doyama H, Tsuji K, Yamada S. Deep colonic endoscopic submucosal dissection using a modified clip and snare method incorporating a pre-looping technique. BMJ Case Rep. (2015) 2015:bcr2014207918. doi: 10.1136/bcr-2014-207918

221. Ritsuno H, Sakamoto N, Osada T, Goto SP, Murakami T, Ueyama H, et al. Prospective clinical trial of traction device-assisted endoscopic submucosal dissection of large superficial colorectal tumors using the S-O clip. Surg Endosc. (2014) 28:3143-9. doi: 10.1007/s00464-0143572-0

222. Jacques J, Charissoux A, Legros R, Tailleur A, Rivory J, Albouis J, et al. Double-clip counter-traction using a rubber band is a useful and adaptive tool for colonic endoscopic submucosal dissection. Endoscopy. (2018) 50:179-81. doi: 10.1055/s-0043-122596 
223. Kantsevoy SV, Bitner M, Piskun G. New endoscopic platform for endoluminal en bloc tissue resection in the gastrointestinal tract (with videos). Surg Endosc. (2016) 30:3145-51. doi: 10.1007/s00464-015-4544-8

224. Uraoka T, Ishikawa S, Kato J, Higashi R, Suzuki H, Kaji E, et al. Advantages of using thin endoscope-assisted endoscopic submucosal dissection technique for large colorectal tumors. Dig Endosc. (2010) 22:18691. doi: 10.1111/j.1443-1661.2010.00992.x

225. Zizer E, Roppenecker D, Helmes F, Hafner S, Krieger Y, Lüth T, et al. A new 3D-printed overtube system for endoscopic submucosal dissection: first results of a randomized study in a porcine model. Endoscopy. (2016) 48:762-5. doi: 10.1055/s-0042-104345

226. Mortagy M, Mehta N, Parsi MA, Abe S, Stevens T, Vargo JJ, et al. Magnetic anchor guidance for endoscopic submucosal dissection and other endoscopic procedures. World J Gastroenterol. (2017) 23:288390. doi: 10.3748/wjg.v23.i16.2883

227. Kantsevoy SV, Levihim S, Agarwal A, Raina A, Thuluvath PJ. 496 a new endoluminal therapeutic platform: results of the first 519 interventions. Gastrointest Endosc. (2020) 91:AB46-7. doi: 10.1016/j.gie.2020.03.297

228. Sapci I, Gorgun E. Advanced colonic polypectomy. Surg Clin N Am. (2020) 100:1079-89. doi: 10.1016/j.suc.2020.08.014

229. Hernandez-Lara A, de Paredes GGA, Rajan E, Storm AC. Step-by-step instruction: using an endoscopic tack and suture device for gastrointestinal defect closure. VideoGIE. (2021) 6:243-5. doi: 10.1016/j.vgie.2021.02.015
230. McCarty TR, Aihara H. Endoscopic submucosal tunneling dissection: use of a novel bipolar radiofrequency and microwave-powered device for colorectal endoscopic submucosal dissection. VideoGIE. (2020) 5:3358. doi: 10.1016/j.vgie.2020.03.018

Conflict of Interest: The authors declare that the research was conducted in the absence of any commercial or financial relationships that could be construed as a potential conflict of interest.

Publisher's Note: All claims expressed in this article are solely those of the authors and do not necessarily represent those of their affiliated organizations, or those of the publisher, the editors and the reviewers. Any product that may be evaluated in this article, or claim that may be made by its manufacturer, is not guaranteed or endorsed by the publisher.

Copyright (c) 2022 Mann, Gajendran, Umapathy, Perisetti, Goyal, Saligram and Echavarria. This is an open-access article distributed under the terms of the Creative Commons Attribution License (CC BY). The use, distribution or reproduction in other forums is permitted, provided the original author(s) and the copyright owner(s) are credited and that the original publication in this journal is cited, in accordance with accepted academic practice. No use, distribution or reproduction is permitted which does not comply with these terms. 